\title{
Redistribution of individual pension wealth to survivor pensions: Evidence from a stated preferences analysis
}

Citation for published version (APA):

de Grip, A., Fouarge, D., \& Montizaan, R. (2020). Redistribution of individual pension wealth to survivor pensions: Evidence from a stated preferences analysis. Journal of Economic Behavior \& Organization, 173, 402-421. https://doi.org/10.1016/j.jebo.2019.09.013

Document status and date:

Published: 01/05/2020

DOI:

10.1016/j.jebo.2019.09.013

Document Version:

Publisher's PDF, also known as Version of record

Document license:

Taverne

Please check the document version of this publication:

- A submitted manuscript is the version of the article upon submission and before peer-review. There can be important differences between the submitted version and the official published version of record.

People interested in the research are advised to contact the author for the final version of the publication, or visit the DOI to the publisher's website.

- The final author version and the galley proof are versions of the publication after peer review.

- The final published version features the final layout of the paper including the volume, issue and page numbers.

Link to publication

\footnotetext{
General rights rights.

- You may freely distribute the URL identifying the publication in the public portal. please follow below link for the End User Agreement:

www.umlib.nl/taverne-license

Take down policy

If you believe that this document breaches copyright please contact us at:

repository@maastrichtuniversity.nl

providing details and we will investigate your claim.
}

Copyright and moral rights for the publications made accessible in the public portal are retained by the authors and/or other copyright owners and it is a condition of accessing publications that users recognise and abide by the legal requirements associated with these

- Users may download and print one copy of any publication from the public portal for the purpose of private study or research.

- You may not further distribute the material or use it for any profit-making activity or commercial gain

If the publication is distributed under the terms of Article 25fa of the Dutch Copyright Act, indicated by the "Taverne" license above, 


\title{
Redistribution of individual pension wealth to survivor pensions: Evidence from a stated preferences analysis
}

\author{
Andries de Grip ${ }^{\mathrm{a}, \mathrm{b}, \mathrm{c}}$, Didier Fouarge ${ }^{\mathrm{a}, \mathrm{b}, \mathrm{c}}$, Raymond Montizaan ${ }^{\mathrm{a}, \mathrm{b}, \mathrm{c}, *}$ \\ ${ }^{a}$ ROA, Maastricht University: PO-box 616, Tongersestraat 53, 6200 MD Maastricht, the Netherlands \\ ${ }^{\mathrm{b}}$ IZA, Bonn, Germany, Schaumburg-Lippe-Straße 5-9, 53113 Bonn, Germany \\ ' Netspar, PO-box 90153, 5000LE, Tilburg, the Netherlands
}

\section{A R T I C L E I N F O}

\section{Article history:}

Received 1 September 2018

Revised 3 September 2019

Accepted 12 September 2019

Available online 23 September 2019

\section{JEL Classification:}

J14

J26

D31

\section{Keywords:}

Stated preferences experiment

Redistribution of pension wealth

Survivors pension

Economic preferences

\begin{abstract}
A B S T R A C T
Pension schemes in the Netherlands allow workers to redistribute their own pension wealth to increase the survivor pension of their partner. However, due to lacking communication and knowledge of survivor pensions among workers, and also due to the lack of transparent products and choice architecture, redistribution remains limited. This paper uses a stated preferences experiment that is explicitly designed for workers with a partner in the age group of 55 to 65 years to elicit their pension redistribution preferences. We find that, on average, the preferred pension wealth redistribution amounts to $50 \% .35 \%$ of all individuals have such a preference. $33 \%$ of all individuals would prefer less redistribution, and $32 \%$ percent prefers to redistribute more pension income to the partner upon one's death. We further show that total family income during working life does not affect the redistribution to survivor pensions. However, the distribution of the contribution to total family income before retirement across partners, as well as the survival likelihood of the partner and the number of years the partner is expected to survive, have a significant causal impact on the preferred pension redistribution decision. The preference for redistribution to survivor pensions also depends significantly on personal characteristics, preferences and social attitude. Males have a significantly stronger preference for redistribution compared to females. Moreover, forward-looking, more risk averse and more altruistic individuals have a stronger preference to redistribute part of their pension wealth to a survivor pension. Finally, in particular when employees have the perception that their partner is more forward looking, they are willing to invest more in a survivor pension.
\end{abstract}

(c) 2019 Elsevier B.V. All rights reserved.

\section{Introduction}

Survivors' pensions are retirement benefits to a person whose spouse (or parent) has died. This social protection for survivors has been present in European society since the end of the 19th century and aims to insure against the social risk that the decease of one person (breadwinner) in the household results in a major loss of income for the other person(s) in the household. In 2014, survivor benefits represented almost $6 \%$ of the total expenses on social benefits in the European Union. This rate is almost equivalent to the social benefits for unemployment (5\%) and disability (7\%) (Eurostat 2017). Since the 1990s, European pension systems have been subject to numerous reforms. These reforms include, among others, decreases in the generosity of pension benefits and increases in the eligibility age for early and statutory retirement

\footnotetext{
* Corresponding author at: ROA/Maastricht University, PO-box 616, Tongersestraat 53, 6200 MD, Maastricht, the Netherlands.

E-mail address: r.montizaan@maastrichtuniversity.nl (R. Montizaan).
} 
(Gruber and Wise, 1998; Duval, 2005; Mastrobuoni, 2009; Hanel, 2010; Kangas et al., 2010; Börsch-Supan, 2012; Staubli and Zweimüller, 2013). The legislation concerning survivors' benefits have also undergone substantial modifications in several European countries (e.g., Denmark, United Kingdom, Greece, and the Netherlands), mostly involving a reduction of public survivor benefits. ${ }^{1}$ Individuals therefore become increasingly responsible for their own pension rights and retirement decisions, as well as for a sufficient pension provision of their surviving spouse (Frericks and Hoeppner, 2018). In the Netherlands, the public first-pillar survivor pension scheme (Surviving Dependents Act (Anw)) has been drastically curtailed, so that only a small percentage of people are still eligible to this benefit. The ensuing gap in household pension wealth has only been partially, in a highly fragmented manner, covered through second-pillar pension schemes (Staarink and Visser, 2017). In the second-pillar pension schemes in the Netherlands, employees are offered the opportunity to individually supplement future survivor pensions at the moment of their retirement by substituting part of the pension benefits until their death by a survivor annuity which continues to make additional payments to the spouse after the death of the retired employee. However, the take-up rate of this redistribution product in the second-pillar pension scheme remains low (only $4 \%$ of employees in the public sector in 2019 decided to invest in the survivor annuity) due to lacking communication and poor knowledge of survivor pensions among employees, but also due to the lack of transparent products and choice architecture. Recent research commissioned by a large insurance company showed that only one in three knows that partner's pension in the second-pillar pension scheme is related to the death of the retired employee (Motivaction, 2019). Moreover, one in three had no idea whether they are entitled to a partner's pension and that more than half of all employees do not know what the partner pension means financially for their partner if the employee would die before the retirement date. Regarding the amount of the partner's pension, however, 25\% of employees report that they will run into financial problems if their partner would die. Therefore, the current take-up rate of redistribution products in the second-pillar pension schemes in the Netherlands will most likely not reflect the true redistribution preferences of employees and needs further investigation. This raises the question to what extent employees are willing to redistribute their own pension wealth to their surviving partner and what actually drives their decision to redistribute.

This paper uses a stated preferences approach to estimate Dutch employees' willingness to redistribute own pension wealth to increase the survivor pension of their partner. When implementing field or lab experiments in a domain such as survivor pension is not easily done, stated preferences experiments are a suitable way to address the issue from a behavioral perspective. Our stated preferences experiment is explicitly designed for individuals with a partner in the age group of 55 years and older who are close to retirement and is part of the ROA Public Sector Employees Survey which was conducted in 2015. The core of our stated preference experiment consists of the choices respondents make between five hypothetical, but mostly realistic, pension redistribution outcomes in six different choice sets (vignette scenarios). These redistribution outcomes differ with respect to (1) the level of the monthly pension benefits until one's death and (2) the actuarially related pension of the widowed partner after one's death. The five consecutive steps of redistribution (in steps of 25\%-points) range from no redistribution, where the widowed partner is only entitled to a first pillar old-age pension that -depending on the vignette scenario can be supplemented with partner's own pension wealth - to full redistribution where the widowed partner receives the same pension income as when his/her partner was still alive.

In the vignettes, four key conditions are randomly changed: (1) monthly family income during working life, (2) the relative contribution to family income of both partners during working life, (3) the probability that the partner lives longer than the respondent, and (4) the duration of the survival of the partner. These conditions have been major determinants in recent overlapping generation models of participation in joint life annuities and labor market behavior of families (e.g., Brown and Poterba, 2000; Vidal-Meliá and Lejárraga-García, 2006; Fehr et al., 2017).

The main reason we use a stated rather than revealed preferences approach is threefold. First, current choices for redistribution of own pension wealth to survivor pensions will most likely lead to an underestimation of the true willingness to redistribute because they do not reflect the actual preferences of employees. This is because the survivor pension options within current pension schemes are hard to comprehend for an average employee since employees are poorly informed and choice options are not always made explicit (Staarink and Visser 2017). Second, the consequences of taking (no) additional insurance for a survivors pension gap is not actively communicated to people and many are therefore unaware of the financial risk which makes revealed preferences data unsuitable. Third, the vignettes we designed ensure that we know the respondent's choice alternatives and the conditions in which the choices are made. The variation in choices is sufficiently large and, by construction, exogenous to preferences, actual pension entitlements of the respondents and their spouses, as well as important conditions such as individual life expectancy and the share of the total household income generated by the respondent. Such conditions are, in general, impossible to meet when using observational data. Because of this exogenous variation, the effects we estimate can be interpreted causally.

Several studies have systematically investigated the extent to which the hypothetical behavior reported in vignette studies compares to actual behavior and show convincing evidence that the data generated through the use of vignettes is

\footnotetext{
${ }^{1}$ For example, in Denmark, if people deceased before 1992, the benefits from the Danish ATP fund (the supplementary pension fund, which is a contribution-related pension) consist of an annuity, while for people who passed away in 1992 or later the benefit is a lump-sum payment. Moreover, if people started to participate in a pension scheme after 2002, the lump-sum payment decreases with age. The UK also introduced a system of lumpsum bereavement payments in 2001, which substituted the previous system of pensions paid exclusively to women. Survivors' benefits paid under this state earnings-related system were then lowered from $100 \%$ to $50 \%$ of the deceased's pension. Changes in legislation in Germany reduced the share of the deceased's pension paid to the surviving spouse for those who married after 2001.
} 
correlated to actual behavior (Peabody et al., 2000, 2004; Eifler, 2007; Telser and Zweifel, 2007; Eggers et al., 2015). In fact, stated preferences experiments are widely used in marketing research (e.g., Louviere et al., 2000), transportation and environmental science (Hensher, 1997), and are also rapidly gaining ground in economics (see, e.g., Barsky et al., 1997; Revelt and Train, 1998; Van Soest et al., 2007; Kantarci and Van Soest, 2008; Braga et al., 2009; Benjamin et al., 2014; Van Soest and Vonkova, 2014; Wiswall and Zafar, 2017; Elsayed et al., 2018).

The results of our analyzes show that the most common level of pension redistribution is $50 \%$ : $35 \%$ of all individuals have such a preference. $33 \%$ of all individuals would prefer less redistribution, and $32 \%$ percent prefers to redistribute more pension income to the partner upon one's death. We further show that the total family income during working life does not play a role in individuals' pension wealth redistribution to the survivor's pension. However, the distribution of the contribution to total family income before retirement across partners does matter for the preferred pension income redistribution. Compared to the situation in which someone contributes $100 \%$ to family income, those who contribute $25 \%$ (and their partner 75\%) have a lower preference for full redistribution. Furthermore, the survival likelihood of the partner and the number of years the partner is expected to survive are significantly positively related to a stronger redistribution to the survivor's pension.

We further find that the preference for redistribution in favor of survivor pensions strongly depends on personal characteristics, preferences and social attitude. Men have a significantly stronger preference for redistribution compared to women. This difference in preferences is economically significant as men have a 5.9\%-point higher probability to choose the full redistribution option compared to women. Age positively correlates with stronger preferences for pension redistribution, while highly educated employees prefer less redistribution. Third, we find that forward looking, more risk averse and more altruistic individuals have a stronger preference to redistribute part of their pension wealth to a survivor pension. Finally, we show that the respondents' perception of the personality traits of their partner also influences their redistribution preferences. Conditional on respondents' own time preference, we find that having a partner who is more forward looking increases the willingness to redistribute. Most interesting, the marginal effect of the perception of the partner's time preference is equal in size to the one of the respondents' own time preference, indicating that survivors pension decisions are likely to be a joint decision and that partner's preferences should not be disregarded when analyzing these decisions.

Most recent studies on the importance of family insurance for social security theoretically analyze these issues on the macro-level using overlapping generation models and focus on the impact of survivors pensions on labor participation (e.g., Nishiyama and Smetters, 2007; Fehr et al., 2008; Kaygusuz, 2015; Sánchez Martín and Sánchez Marcos, 2010; Fehr et al., 2017; Nishiyama 2019). These studies primarily depend on simulation techniques to establish that survivor pensions discourage labor market participation of married women and, hence, can have negative welfare effects. However, the simulation studies of Nishiyama and Smetters (2007) and Fehr et al. (2008) also show that when intergenerational redistribution is neutralized via compensating transfers, the insurance benefits of social security dominate the cost arising from labor supply distortions and stronger liquidity constraints both in the US and in Germany. These studies do, however, not provide us with micro-economic empirical evidence on who invests in or foregoes survivor protection in pension annuities. This literature is much smaller, and although it provides valuable insights into annuitization choices, most previous empirical studies use outdated data for the United States (Holden et al., 1986; Myers et al., 1987; Turner, 1988; Holden and Nicholson, 1998; Johnson et al., 2005). An additional drawback of the existing research is that it was motivated by concerns about the retirement security of widows, implying that most of these studies focus exclusively on the annuitization decisions of married men (e.g., Holden et al., 1986; Holden and Nicholson, 1998). Moreover, only a few of these studies examined the decision to engage in a survivors' pension plan at the time retiring employees have to make this choice. Instead, most of these studies on survivor protection focus on current characteristics of individuals who are already retired, although it is likely that the decision to invest in a survivors' pension plan was made many years earlier. ${ }^{2}$

This study contributes to the literature on survivor's pensions in several ways. First, we add to the literature by reconsidering survivor pension decisions by using recent data that better fit into the current legal, social, and economic environment and are also more closely related to the European context. Second, the stated preferences approach allows us to elicit more accurately the true preferences for survivor's protection than previous studies that rely on revealed preferences, as the survivor pension options within current pension schemes are hard to comprehend for an average employee. Third, the randomization of the key conditions in the vignettes further allows us to make causal claims about the relative importance of the monthly family income during working life, the relative contribution to family income of both partners during working life, the probability that the partner survives longer than the respondent, and the duration of the survival of the partner. Fourth, we further contribute by also considering the survivor pension decisions of women. This is important because female labor market participation has been increasing in most European countries, and married women therefore retire with increasingly substantial work experience and pension wealth in their own names, implying that their annuitization choices can no longer be ignored. Finally, we go beyond previous studies by showing that the redistribution of pension wealth to survivor pensions

\footnotetext{
2 Johnson et al. (2005) is a notable exception who focused on survivor pension decisions of both gender types. This study examines the payout decision and measures the share of married retirees in the United States with pension annuities who forego survivor protection somewhat more recently (until 2001 ) and shows that one quarter (28\%) of married men and two thirds of married women receiving employer-sponsored retirement annuities declined survivor protection.
} 
in the Netherlands strongly depends on personality characteristics such as time preferences, risk preferences and altruism as well as respondent's perceptions of their partner's economic preferences. ${ }^{3}$

This paper proceeds as follows. Section 2 describes the Dutch pension system and the first pillar survivors pension scheme. Section 3 describes the data, experimental design, and variables used in the analyses. Section 4 presents the main analyses. Section 5 discusses several robustness checks. Finally, Section 6 summarizes our findings and sets forth our conclusions.

\section{Dutch retirement system}

\subsection{Pillars of the Dutch retirement system}

Although our stated preference experiment uses vignettes in which respondents had to make a choice between hypothetical pension schemes, it is important to have a good overview of the Dutch retirement system in order to see to what extent the hypothetical pension schemes are realistic for the respondents.

The Dutch pension system consists of three pillars (see De Grip et al. $(2012,2013)$ for more details). The first consists of a flat-rate public scheme (AOW) to which all citizens are entitled, regardless of whether they are employee, self-employed, or never participated in the labor market. The AOW provides Dutch citizens with a pension benefit that guarantees $70 \%$ of the net minimum wage for a single household and 50\% for each partner in a couple (either married or officially living together). For decades, the eligibility age for the AOW was 65. Due to recent reforms in 2013 and 2015, the eligibility age for the AOW is gradually increasing to 66 years in 2018 and 67 in 2021. After 2021, the eligibility age will be linked to life expectancy in the Netherlands. By this algorithm the eligibility age for the AOW has recently been further increased to 67 years and 3 months in 2022 .

The second pillar consists of supplementary earnings-related pensions. This is a (hybrid $)^{4}$ defined-benefit type of pension for employees organized at the sector or firm level. Sector pensions are negotiated between unions and employer organizations at the sector or firm level and are in most cases set forth in collective agreements. Participation is mandatory, ensuring that each employee is covered by sector pensions. The Pensions and Savings Act (Pensioen en Spaarfondsenwet) until 2007 and the Pensions Act from 2007 onwards (Pensioenwet) dictate that the administration of the sector pension schemes in the second pillar is delegated to pension funds to which both employers and employees have to contribute. Pension benefits in the second pillar are based on the average wage employees have built up over their entire career. These average wage schemes have by now almost totally replaced the final salary schemes, based on employees' last wage. The second pillar pension can be used to retire early or late, before or after the eligibility age for the state pension. ${ }^{5}$ The earliest age people can claim second pillar pension benefits is 60 years, while the latest age is 70 years. Replacement rates depend on the age at retirement. Early retirement leads to lower benefits.

The third pillar includes all voluntarily built-up savings that are in addition to the first two pillars. Due to the wellestablished first two pillars of the Dutch pension system, the third pillar is less developed in the Netherlands than in other countries. The first two pillars combined already generate pension replacement rates that are amongst the most generous in the world (OECD 2017). ${ }^{6}$

\footnotetext{
${ }^{3}$ This paper also contributes to the literature on non-unitary models of household behaviors. Non-unitary models of pension savings do no not consider retirees as isolated individuals, but consider the saving and consumption decisions of elderly couples as the outcome of a joint decision-making process that reflects the preferences and interests of both husband and wife and allows for the dissolution of a marriage through death (e.g., Browning 2000; Lundberg \& Ward-Batts 2000). The non-unitary model allows the couple to "bargain" over the savings and consumption path. Several household bargaining models have been introduced, including cooperative (Manser and Brown 1980, McElroy and Horney 1981, Lundberg and Pollak 1993), non-cooperative models (Lundberg and Pollak 1994), and general collective models (Chiappori 1988, 1992) which do not impose a bargaining scheme, but assume a Pareto efficient outcome. As summarized by Browning (2000), the bargaining approach can be outlined as follows. The household utility function can be expressed as a weighted sum of the individual utility functions of the partners where the weight carries a natural interpretation in terms of relative decision power. Weights can be influenced by a number of factors including individual characteristics of the spouses as well as background variables affecting family structure and society in general. A typical conclusion of these bargaining models is that the greater the share that the wife contributes to the family income, the greater her bargaining power will be over the saving decision and as a result household retirement savings will be higher. However, more recent models also allow for bequest motives and altruism (Vidal-Meliá and Lejárraga-García 2006; Donni and Chiappori 2011). In these models, individual preferences depend not only on one's own consumption, but also on that of the partner. The stated preferences experiment in our paper and the analyses in which we include personality traits of both partners (such as altruism and risk aversion) fit closely to the non-unitary bargaining models with bequests motives of Vidal-Meliá and Lejárraga-García (2006) and Donni and Chiappori (2011). Our results indeed show that higher altruism and time preferences levels of our respondents lead to higher redistribution levels and that they take the personality traits of their partner into account. The only difference with standard bargaining models is that we find that the greater the share oneself contributes to the family income, the more they are willing to redistribute. This seems in first instance counterintuitive in the bargaining model as an increased share also implies that the respondent has a better bargaining position. In second, instance, however, it is important to notice that a greater share in the family income before retirement also implies a greater drop in pension income after one's own death. In combination with the strong impact of the time preferences of the partner, such behavior is still consistent with that in non-unitary bargaining models.

${ }^{4}$ The second pillar pension moved into a hybrid defined-benefit type of pension because the indexation of benefits to inflation has become conditional on the pension fund's financial position and is therefore linked to financial market developments (Ponds and van Riel, 2009).

${ }^{5}$ Although compensation for inflation is the default for supplementary earnings-related pensions, it has not been given in the last few years, due to the rising ratio between liabilities and assets of almost all pension funds.

${ }^{6}$ The net pension replacement rates in Austria, Hungary, Spain, Portugal, Luxembourg, and the Slovak Republic are rather similar to those in the Netherlands.
} 
In 2015, the first two pillars yielded a gross replacement rate of about $69 \%$ (of the average wage) when an employee with an intermediate vocational education degree in the public sector retired full-time at age 64. This employee experienced an accrual rate of approximately $5 \%$ for each year he or she retires earlier (people can retire from 60 years onwards) or later (until age 70 ). This implies that the gross replacement rate would be about $65 \%$ when retiring at age 63 , approximately $80 \%$ when retiring at age 66 (the new eligibility age for the AOW in 2018), and approximately 99\% when retiring at age $70 .^{7}$ For employees with a Bachelor or University degree who are in the upper quintiles of the Dutch income distribution, and who represent the large majority of the working population within the public sector in the Netherlands, the first two pillars yielded a gross replacement rate between 64\% and 53\% (Knoef et al., 2017). Note that the gross replacement rate is lower for higher educated employees as the AOW benefit becomes relatively smaller compared to the income which these employees earned before retirement.

\subsection{Survivors pensions in the Netherlands}

In the Netherlands, in case a partner or ex-partner has passed away, those who were financially dependent on the deceased are entitled to a benefit under the General Surviving Relatives Act (Algemene nabestaandenwet, ANW benefit). The amount of the surviving relative's benefit depends on the income of the surviving relative. There is a maximum of $70 \%$ of the minimum wage. The deceased partner must have been insured when he/she passed away; in other words, he or she must have lived in the Netherlands or have worked and paid tax in the Netherlands.

Everyone who lives or works in the Netherlands is automatically insured under the ANW. Eligibility for a benefit under the ANW, however, depends on very specific conditions. The partner of a deceased insured person is entitled to an ANW benefit if: (1) he or she has an unmarried child who is under the age of $18,(2)$ is expecting a child, (3) or is more than $45 \%$ incapacitated for work. The ANW benefit stops if the partner no longer has an unmarried child who is under 18 (or the child goes to live in another household), is no longer more than $45 \%$ incapacitated for work, reaches the statutory retirement age under the General Old Age Pensions Act (AOW), remarries or starts living together with a partner.

Because of these strict eligibility rules, only a small fraction of partners is eligible for an ANW benefit. Employees therefore increasingly depend on building up a survivors pension for their partner within the second pillar supplementary pension schemes or private life insurance with their surviving spouse as beneficiary.

In the second-pillar pension schemes, employees are offered the opportunity to individually supplement future survivor pensions at the moment of their retirement by substituting part of the pension benefits until their death by a survivor annuity which continues to make additional payments to the spouse after the death of the retired employee. The partner pension may be maximal $70 \%$ of the old-age pension rights.

\section{Data and experimental design}

\subsection{Data collection}

The Dutch public sector's pension fund (ABP) gave us access to 7520 randomly selected e-mail addresses of public sector employees born between 1952 and 1975. In the first week of April 2015, we sent an e-mail to these employees containing the link to a web-based survey (the ROA Public Sector Survey 2015). This survey included questions on individual characteristics, sources of income after retirement, partner characteristics and the stated preferences experiment we use to investigate employees' preferences for redistribution of individual pension wealth to survivor pensions. Because Eggers et al. (2015) showed that preferences observed in stated-preference experiments in particular are close to revealed preferences when respondents' engagement with the choices to be made is high, we select 1602 working respondents who have a partner and are aged 55-65 years in our estimation sample. ${ }^{8}$

The stated preferences experiment includes vignettes that focus on various pension redistribution scenarios from pension income to the survivor pension of their partner. These vignettes are the basis of our analyses. As all respondents replied to six vignettes, we have 9612 observations of employees' choices with respect to the redistribution of their pension income to the survivor pension of their partner. Our final estimation sample includes 9511 observations for 1585 respondents. This is because of limited item non-response in the personal characteristics which are measured in the survey and are used in our analyses.

\subsection{Stated-preference experiment}

Our stated-preference experiment is explicitly designed for individuals aged between 55 and 65 years and who are not yet retired and uses vignettes in which individuals had to choose between various hypothetical, yet realistic pension re-

\footnotetext{
7 This is under the condition that workers work full-time and have no gaps in yearly contributions to the public sector's pension fund.

8 We dropped 316 employees who do not have partner from our estimation sample. To check the representativeness of our estimation sample, we use administrative data of the pension fund to compare basic characteristics of the employees in the population sample (all clients of the occupational pension fund) with those in the estimation sample. Although our sample could differ from the population in ways that not observable to us, we find that there are no significant differences in observables such as age, wage, sector of occupation, and number of contractual work hours of employees between the two samples.
} 
Table 1

Stated preferences scenarios, corresponding pensions, and redistributive choice options.

\begin{tabular}{|c|c|c|c|}
\hline Conditions & Levels & $\begin{array}{l}\text { Corresponding family pension } \\
\text { when both partners are alive } \\
\text { without redistribution }\end{array}$ & $\begin{array}{l}\text { Corresponding pension of } \\
\text { widowed partner without } \\
\text { redistribution }\end{array}$ \\
\hline \multirow[t]{3}{*}{ Family income during working life } & 5000 & 3500 & \\
\hline & 6250 & 4375 & \\
\hline & 7500 & 5250 & \\
\hline \multirow{12}{*}{$\begin{array}{l}\text { Contribution to family income during } \\
\text { working life }\end{array}$} & $100 \%$ oneself - $0 \%$ partner & 3500 & 1150 \\
\hline & $75 \%$ oneself - $25 \%$ partner & 3500 & 1150 \\
\hline & $50 \%$ oneself - $25 \%$ partner & 3500 & 1750 \\
\hline & $25 \%$ oneself- $75 \%$ partner & 3500 & 2625 \\
\hline & $100 \%$ oneself - $0 \%$ partner & 4375 & 1150 \\
\hline & $75 \%$ oneself $-25 \%$ partner & 4375 & 1150 \\
\hline & $50 \%$ oneself $-25 \%$ partner & 4375 & 2188 \\
\hline & $25 \%$ oneself- $75 \%$ partner & 4375 & 3281 \\
\hline & $100 \%$ oneself $-0 \%$ partner & 5250 & 1150 \\
\hline & $75 \%$ oneself - $25 \%$ partner & 5250 & 1313 \\
\hline & $50 \%$ oneself $-25 \%$ partner & 5250 & 2625 \\
\hline & $25 \%$ oneself-75\% partner & 5250 & 3938 \\
\hline \multirow[t]{3}{*}{ Survival probability partner } & $40 \%$ & & \\
\hline & $60 \%$ & & \\
\hline & $80 \%$ & & \\
\hline \multirow[t]{3}{*}{ Duration survival of partner } & 3 years & & \\
\hline & 5 years & & \\
\hline & 8 years & & \\
\hline \multicolumn{4}{|c|}{ Dependent variable: redistributive choice options } \\
\hline \multirow{6}{*}{$\begin{array}{l}\text { Smoothing of partners pension before } \\
\text { and after own death }\end{array}$} & & & \\
\hline & $0 \%$ & & \\
\hline & $25 \%$ & & \\
\hline & $50 \%$ & & \\
\hline & $75 \%$ & & \\
\hline & $100 \%$ & & \\
\hline
\end{tabular}

distribution scenarios. The stated preference experiment was introduced by a short text explaining the topic, after which employees were assigned to six vignettes. Fig. A1 in the Appendix shows the introductory text and an example vignette.

In each vignette respondents have to choose between 5 redistribution options that differ with respect to (1) the level of the monthly pension benefits until one's own death and (2) the actuarially related pension of the widowed partner after one's own death. The five options refer to a smoothing of the difference between the level of the pension benefits until one's own death and the level of the pension of the widowed partner by $0 \%$ up to $100 \%$.

There are four conditions which define the situation in which the redistribution choices are made. ${ }^{9}$ These conditions refer to (1) gross monthly family income during working life ranging from 5000, 6250, to 7500 Euro, (2) the relative contribution to family income of both partners during working life (ranging from $100 \%$ oneself \& $0 \%$ partner, $75 \%$ oneself \& $25 \%$ partner, $50 \%$ oneself \& $50 \%$ partner, to $25 \%$ oneself \& $75 \%$ partner), (3) the probability that the partner lives longer than the respondent ranging from $40 \%, 60 \%$, to $80 \%$, and (4) the duration of the survival of the partner, ranging from 3,5 , to 8 years. ${ }^{10}$ The values of the four relevant conditions exogenously vary across the vignettes as they are randomly drawn from the set of possible levels. Table 1 presents an overview of the conditions and their values in the vignettes. ${ }^{11}, 12$

These four conditions for the redistribution choices are carefully chosen based on the existing literature. The gross family income has been included as earlier work shows that couples with low income tend to elect single life annuities, maximizing their pension income when both spouses are alive and assuming the risk that the spouse will outlive the pensioner (Holden et al., 1986). The gross family income of 6250 euro in the experiment closely matches actual gross family income in

\footnotetext{
9 The number of conditions (independent variables) in the vignettes is commonly reduced to only a very limited number because research indicates that the human brain can cope with only a limited number of factors (Millar, 1956: Larichev and Moshkovich, 1988; Simon, 1990). Including more conditions would decrease the reliability of the results of the experiment. By focusing on a limited number of key conditions we maintain the internal validity of the vignette experiment.

${ }^{10}$ The maximum survivors pension which can be build up is $70 \%$ of the old-age pension rights. In the vignette experiment we allow workers to redistribute pension income beyond this limit in order to get a more comprehensive overview of the preferences for redistribution.

11 Table A1 further shows how two different randomization scenarios affect the randomization choice options displayed to the respondent. It shows that when partners contribute more to the household income, the gap in their survivor pension is lower. Table A2 in Appendix A indicates that the randomization of the various values resulted in an equal distribution over the values distinguished in all four conditions.

12 Table 1 shows that a family income of 5,000 euro generates a joint pension of 3,500 euro. Assuming roughly that the state pension (AOW) for the partner is 800 when both patterns are alive, the combined occupational and state pension income of the respondent is than 2,700 euro. This leads to a gross replacement rate of $2700 / 5000=0.54$ in retirement which is equivalent to replacement rate of people in the upper quintiles of Dutch income distribution. This is rather realistic scenario as the large majority of the working population within the public sector in the Netherlands is actually highly educated and earns a wage which falls in these quintiles (see also the descriptive statistics).
} 
Table 2

Descriptive statistics.

\begin{tabular}{lll}
\hline Characteristic & Average & Standard deviation \\
\hline Age & 60.86 & 2.87 \\
Gender (1 if male) & 0.79 & 0.41 \\
High educated & 0.73 & 0.44 \\
Time preference & 6.87 & 1.98 \\
Risk preference & 6.20 & 2.12 \\
Altruism & 101.08 & 146.56 \\
Observations & 1585 & \\
\hline
\end{tabular}

the Dutch public and education sector as indicated by the LISS panel data 2017). We have deliberately chosen for gross replacement rates to avoid considerations about other income sources. Moreover, a progressive tax rate with four tax brackets applies to income in the Netherlands, making it difficult to determine for each scenario and preferred redistribution level how much pension benefits people would receive net. In the vignettes, respondents are explicitly instructed that the income amounts are gross and not net.

The share in the contribution to the household income before retirement is important as it has major implications for the loss in pension income of the survivor. The lower one's share is to the contribution to the household income before retirement, the lower one's share is to the total pension wealth. Hence, employees whose partner have pension coverage from their own employers should be automatically less inclined to invest in survivors pensions (Johnson et al., 2005). Moreover, evidence by Boskin and Kotlikoff (1985), Altonji et al. (1992), and Wilhelm (1996) show that the distribution of consumption within extended families is strongly dependent on the distribution of resources within extended families. It is therefore of vital importance to include the share in the contribution to the household income as a context condition into our stated preferences experiment.

The survival probability (the probability that the partner lives longer) and the duration of survival are relevant as the chances that the spouse will eventually receive survivor benefits generally increase when the pensioner has health problems. Retirees in poor health with shorter life expectancies than their spouses are especially likely to select survivor annuities over single life annuities (Holden et al., 1986; Turner, 1988; Holden and Nicholson, 1998; Johnson et al., 2005).

\subsection{Personal characteristics and preferences}

Our survey also includes various personal characteristics that have been shown to affect investment decisions and are likely to also influence employees' decisions on the extent to which they will redistribute their future pension wealth to a survivors pension for their partner. We include data on respondents' gender, age, and level of education. ${ }^{13}$ Furthermore, we include variables with respect to respondents' time preference, risk aversion, and altruism. Time preference is measured with the survey question 'How willing are you to give up something that is beneficial for you today in order to benefit more from that in the future?' Respondents could answer on a scale from 0-10 where 0 indicated 'completed unwilling to do so' and 10 indicated 'very willing to do so'. Risk aversion is measured by a subjective risk question. Respondents indicate on a scale from 0-10 to what extent the following statement applies to them: 'How do you see yourself: are you a person who is generally willing to take risks, or do you try to avoid risks? Please self-grade your choice (ranging between 0 (extremely risk averse) and 10 (extremely willing to take risks))' Altruism is measured using the answers of the following question 'Imagine the following situation: today you unexpectedly received 1000 euro. How much of this amount would you give to charities without expecting anything in return?'. These three survey questions have been widely used in behavioral literature and have been extensively validated in incentivized lab experiments (see, e.g., Dohmen et al., 2011 and Falk et al., 2018) which makes it unlikely that social desirability is an important issue when using such survey questions to measure traits and preferences. For our regression analyses, we standardize these measures.

Finally, the survey asked respondents to indicate how their partner would score on the same measures for time preference, risk aversion, and altruism using exactly the same questions and answer scales. The answers to these questions can be relevant for the decision to redistribute pension income when financial decisions in the household are made jointly by both partners. However, it should be noted that it only concerns respondents' perception of their partners' economic preferences. Most likely, these measures include considerable measurement error.

\subsection{Descriptive statistics}

Table 2 shows summary statistics of respondents' main background characteristics. We observe that on average the respondents are almost 61 years old, implying that they are close to retirement.

\footnotetext{
13 On top of one's own age the actual age of the partner could matter in how respondents make their choices even in the context of the stated choice experiment in which partners are assumed to have the same age. Our analyses in Table 6 in which we control for the partner's age, and thereby for the actual age difference between partners, shows that our main findings are not affected.
} 


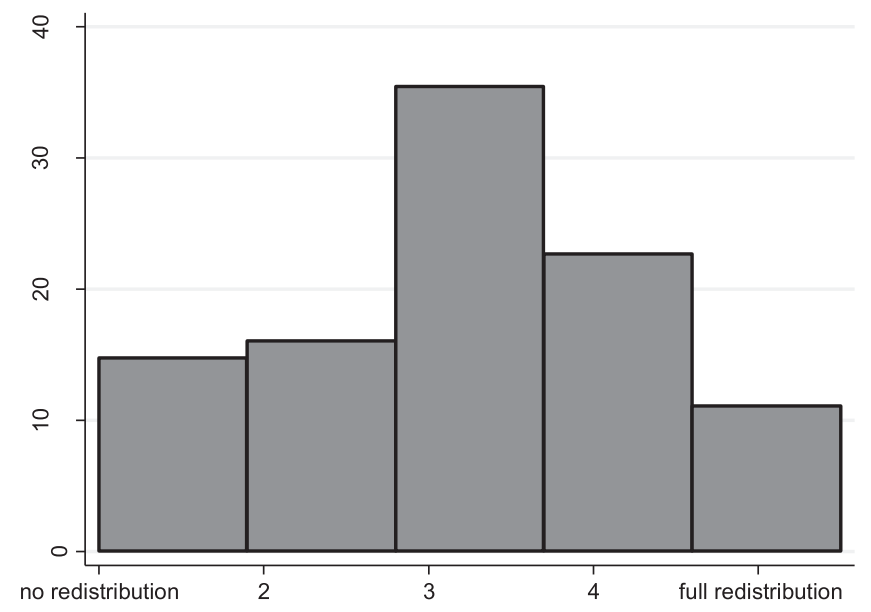

Fig. 1. Pension redistribution.

In each vignette of the stated preferences experiment, respondents have to choose between 5 redistribution options that differ with respect to (1) the level of the monthly pension benefits until one's own death and (2) the actuarially related pension of the widowed partner after one's own death. Redistribution ranges from 1 (no redistribution) to 5 (full redistribution) on the $x$-axis. Fig. 1 shows the distribution of the respondents' redistribution choices in the experiment. The $y$-axis indicates how often a redistribution option is chosen (in percentages).

The table further shows that the majority of respondents in our analysis are male and highly educated. The proportion of highly educated public sector employees in our sample is consistent with the fraction of highly educated public sector employees in other representative data sets, such as the Dutch Labour Supply Panel and the Dutch Labour Force Survey. Respondents, on average, score 6.88 on the time preference scale and 6.20 on the risk aversion scale, respectively. These average scores and their underlying distributions are very close to those found in other surveys (Dohmen et al., 2011). Finally, respondents are, on average, willing to give 101 euros of in total 1000 euros to charities. Note, however, that the standard deviation is large: $28.81 \%$ of all respondents are not willing to give anything, while $13.68 \%$ is willing to give 50 euro, $25.83 \%$ is willing to give 100 euro and $12.78 \%$ is willing to give 200 euro or more.

\subsection{Empirical strategy}

The experimental design of our study allows us to estimate an ordered probit model in which we regress the preferred redistribution level on the conditions which values exogenously vary over the vignettes. By doing so, we identify to what extent the redistribution preferences depend on family income, the contributions of both partners to the family income, the survival probability of the partner and the number of years the partner is expected to survive. The main reason for using an ordered probit model is that our dependent variable takes a number of finite and discrete values that contain ordinal information. The ordered probit model therefore provides an appropriate fit to these data, preserving the ordering of the retirement redistribution response options while making no assumptions of the interval distances between the options. We present the marginal effects of the coefficients of the ordered probit model for all five redistribution outcomes for our basic analyses in which we analyze the impact of the vignette attributes on the willingness to redistribute. In subsequent analyses, due to space constraints, we proceed with showing the marginal effects for the full redistribution outcome (outcome 5 on the redistribution scale). ${ }^{14}$ Because all respondents replied to six choice sets, we use a clustered sandwich estimator to allow for intragroup correlation at the individual level (Rogers 1993; Wooldridge 2002).

\section{Results}

\subsection{Descriptive results}

In the stated preferences experiment, we allow respondents to redistribute joint pension income towards a survivor' pension given a randomized set of changing conditions. As mentioned, the experiment incorporates five consecutive steps of redistribution (in steps of 25\%) ranging from no redistribution, where the widowed partner is only entitled to standard oldage pension, to full redistribution where the widowed partner receives the same pension income as when his/her partner was still alive. Fig. 1 shows that the preferred levels of pension redistribution is 50\%: $35 \%$ of all individuals have such a preference, irrespective of the attributes of the stated choice experiment. A potential worry is that respondents choose for $50 \%$ redistribution because the exercise in the vignette is hard for them to comprehend, and they go for the mid-point in

\footnotetext{
${ }^{14}$ We also performed analyses for the other redistribution outcomes and found results in line with those reported here.
} 
Table 3

Basic model with attributes in experiment.

\begin{tabular}{|c|c|c|c|c|c|}
\hline $\begin{array}{l}\text { Dependent variable: Pension redistribution Marginal effects of } \\
\text { ordered probit }\end{array}$ & $\begin{array}{l}(1) \\
\text { predict } \\
(\text { outcome }(\# 1))\end{array}$ & $\begin{array}{l}(2) \\
\text { predict } \\
\text { (outcome(\#2)) }\end{array}$ & $\begin{array}{l}\text { (3) } \\
\text { predict } \\
\text { (outcome(\#3)) }\end{array}$ & $\begin{array}{l}(4) \\
\text { predict } \\
\text { (outcome(\#4)) }\end{array}$ & $\begin{array}{l}(5) \\
\text { predict } \\
\text { (outcome(\#5) }\end{array}$ \\
\hline \multicolumn{6}{|l|}{ Family income during working life } \\
\hline $\begin{array}{l}\text { Family Income during working life }=6250 \text { (low income } \\
(5000)=\text { ref.) }\end{array}$ & $\begin{array}{l}0.005 \\
(0.006)\end{array}$ & $\begin{array}{l}0.002 \\
(0.003)\end{array}$ & $\begin{array}{l}0.000 \\
(0.000)\end{array}$ & $\begin{array}{l}-0.003 \\
(0.005)\end{array}$ & $\begin{array}{l}-0.004 \\
(0.005)\end{array}$ \\
\hline Family Income during working life $=7500$ & $\begin{array}{l}0.001 \\
(0.006)\end{array}$ & $\begin{array}{l}0.001 \\
(0.003)\end{array}$ & $\begin{array}{l}0.000 \\
(0.000)\end{array}$ & $\begin{array}{l}-0.001 \\
(0.005)\end{array}$ & $\begin{array}{l}-0.001 \\
(0.005)\end{array}$ \\
\hline \multicolumn{6}{|l|}{ Contribution to family income during working life } \\
\hline $75 \%$ oneself and $25 \%$ partner $(100 \%$ oneself $=$ ref.) & $\begin{array}{r}-0.006 \\
(0.004)\end{array}$ & $\begin{array}{l}-0.005 \\
(0.003)\end{array}$ & $\begin{array}{l}-0.003 \\
(0.002)\end{array}$ & $\begin{array}{l}0.005 \\
(0.004)\end{array}$ & $\begin{array}{l}0.008 \\
(0.006)\end{array}$ \\
\hline $50 \%$ oneself and $50 \%$ partner & $\begin{array}{l}0.078^{* * *} \\
(0.007)\end{array}$ & $\begin{array}{l}0.046^{\text {**** }} \\
(0.004)\end{array}$ & $\begin{array}{l}0.006^{* *} \\
(0.003)\end{array}$ & $\begin{array}{l}-0.063^{\text {*** }} \\
(0.006)\end{array}$ & $\begin{array}{l}-0.068^{* * *} \\
(0.006)\end{array}$ \\
\hline $25 \%$ oneself and $75 \%$ partner & $\begin{array}{l}0.121^{* * *} \\
(0.010)\end{array}$ & $\begin{array}{l}0.062^{\text {*** }} \\
(0.005)\end{array}$ & $\begin{array}{c}-0.004 \\
(0.005)\end{array}$ & $\begin{array}{l}-0.091^{\text {*** }} \\
(0.008)\end{array}$ & $\begin{array}{l}-0.088^{* * *} \\
(0.006)\end{array}$ \\
\hline \multicolumn{6}{|l|}{ Likelihood that partner survives } \\
\hline Likelihood that partner survives: $60 \%$ ( $40 \%=$ ref.) & $\begin{array}{l}-0.016^{* * *} \\
(0.006)\end{array}$ & $\begin{array}{l}-0.009^{* * *} \\
(0.003)\end{array}$ & $\begin{array}{l}-0.001 \\
(0.001)\end{array}$ & $\begin{array}{l}0.012^{* * * *} \\
(0.004)\end{array}$ & $\begin{array}{l}0.014^{* * * *} \\
(0.005)\end{array}$ \\
\hline Likelihood that partner survives: $80 \%$ & $\begin{array}{l}-0.020^{* * *} \\
(0.006)\end{array}$ & $\begin{array}{l}-0.011^{\text {**** }} \\
(0.003)\end{array}$ & $\begin{array}{l}-0.001 \\
(0.001)\end{array}$ & $\begin{array}{l}0.015^{* * *} \\
(0.005)\end{array}$ & $\begin{array}{l}0.017^{\text {***** }} \\
(0.005)\end{array}$ \\
\hline \multicolumn{6}{|l|}{ Number of years that partner survives } \\
\hline Years that partner survive: 5 ( $3=$ ref.) & $\begin{array}{l}-0.016^{* * *} \\
(0.006)\end{array}$ & $\begin{array}{l}-0.008^{* * *} \\
(0.003)\end{array}$ & $\begin{array}{l}0.000 \\
(0.001)\end{array}$ & $\begin{array}{l}0.012^{* * *} \\
(0.005)\end{array}$ & $\begin{array}{l}0.012^{\text {**** }} \\
(0.005)\end{array}$ \\
\hline Years that partner survive: 8 & $\begin{array}{l}-0.028^{* * *} \\
(0.006)\end{array}$ & $\begin{array}{l}-0.015^{* * *} \\
(0.003)\end{array}$ & $\begin{array}{l}-0.001 \\
(0.001)\end{array}$ & $\begin{array}{l}0.021^{* * *} \\
(0.005)\end{array}$ & $\begin{array}{l}0.023^{\text {**** }} \\
(0.005)\end{array}$ \\
\hline Observations & 9511 & 9511 & 9511 & 9511 & 9511 \\
\hline
\end{tabular}

The table shows marginal effects. Clustered standard errors in parentheses. Income redistribution is measured on a 5-points scale where 1 indicates that no pension redistribution takes place and 5 means that full pension distribution takes place. ${ }^{* * *} p<0.01,{ }^{* *} p<0.05,{ }^{*} p<0.10$.

our answer scale as the 'safe' option. It is comforting to see that $30 \%$ of the respondents never choose for $50 \%$ in any of the 6 rounds, and that only $6 \%$ choose for $50 \%$ redistribution in all 6 rounds. ${ }^{15}$ Fig. 1 also shows that $33 \%$ of all individuals would prefer less or no redistribution. This result is close to the results found by Johnson et al. (2005) for the United States in the 1990s. Using data from the Health and Retirement Study, they found that 28\% of married men receiving employer-sponsored retirement annuities declined spousal survivor protection during the period between 1992 and 2000. However, we also find that $32 \%$ would prefer to redistribute more pension income to the partner upon one's death. 11\% of all employees would even be willing to completely smooth joint pension income and the survivor pension of their partner. This is remarkable as this redistribution option almost always leads to a drop in net pension wealth of the household (including the accumulation of the joint pension benefits as well as the survivor's pension benefits).

\subsection{Basic model estimates}

We regress the preferred level of pension redistribution on the conditions set in the stated choice experiment using an ordered probit model. Table 3 reports the marginal effects of the estimation results. Columns 1-5 show the marginal effects on each potential redistribution outcome. The table shows that the total family income during working life does not play a role for the redistribution of pension income in favor of the surviving partner. This seems inconsistent with existing studies on survivor pensions in the United States, which show that low-income couples tend to invest in single life annuities instead of survivors pensions (Holden et al., 1986).

We further find, however, that the relative contribution to the household income of the two partners before retirement does substantially matter for the preferred pension income redistribution. Compared to the situation in which individuals contribute $100 \%$ to family income, those who contribute $25 \%$ (and their partner $75 \%$ ) have much a lower preference for redistribution. This also holds to a lesser extent for households with a 50-50 contribution to the total household income. Columns 1 until 5 show that a 25-75\% contribution induces respondents more often to choose for no redistribution. Outcome 1 (no redistribution) is chosen 12.1\%-points more often in households with a 25-75\% contribution compared to household with a 100-0\% contribution). Full-redistribution (outcome 5) is chosen 8.8\%-points less often by the respondents in this situation. This result for the relative contribution to the household income of the two partners is consistent with our expectations as a different contribution to household income also implies a different pension after the spouse has deceased. Indeed, when one's own contribution to the household income is higher before retirement, this also means that until one's death the household will depend more on the pension income which is built up during one's own work life. The higher own contribution automatically implies that the partner had a relatively lower own income before retirement and therefore

\footnotetext{
15 Moreover, in a sensitivity analysis, discussed in the robustness checks section, we removed respondents who choose for $50 \%$ redistribution (see Table 8 ). This does not affect our main conclusions.
} 
Table 4

Explaining pension redistribution.

\begin{tabular}{|c|c|c|c|c|}
\hline $\begin{array}{l}\text { Ordered probit: Marginal effects of the predicted probability for the } \\
\text { largest redistribution }\end{array}$ & $(1)$ & $(2)$ & (3) & $(4)$ \\
\hline \multicolumn{5}{|l|}{ Vignette characteristics } \\
\hline \multicolumn{5}{|l|}{ Family income during working life } \\
\hline Family Income during working life $=6250$ (low income $(5000)=$ ref.) & $\begin{array}{l}-0.003 \\
(0.005)\end{array}$ & $\begin{array}{l}-0.003 \\
(0.005)\end{array}$ & $\begin{array}{l}-0.002 \\
(0.005)\end{array}$ & $\begin{array}{l}-0.002 \\
(0.005)\end{array}$ \\
\hline Family Income during working life $=7500$ & $\begin{array}{l}-0.001 \\
(0.005)\end{array}$ & $\begin{array}{l}-0.001 \\
(0.005)\end{array}$ & $\begin{array}{l}-0.000 \\
(0.005)\end{array}$ & $\begin{array}{l}-0.001 \\
(0.005)\end{array}$ \\
\hline \multicolumn{5}{|l|}{ Contribution to family income during working life } \\
\hline $75 \%$ oneself and $25 \%$ partner $(100 \%$ oneself $=$ ref.) & $\begin{array}{l}0.008 \\
(0.006)\end{array}$ & $\begin{array}{l}0.007 \\
(0.006)\end{array}$ & $\begin{array}{l}0.007 \\
(0.006)\end{array}$ & $\begin{array}{l}0.007 \\
(0.006)\end{array}$ \\
\hline $50 \%$ oneself and $50 \%$ partner & $\begin{array}{l}-0.068^{* * *} \\
(0.006)\end{array}$ & $\begin{array}{l}-0.067^{\text {**** }} \\
(0.006)\end{array}$ & $\begin{array}{l}-0.067^{\text {**** }} \\
(0.006)\end{array}$ & $\begin{array}{l}-0.068^{\text {**** }} \\
(0.006)\end{array}$ \\
\hline $25 \%$ oneself and $75 \%$ partner & $\begin{array}{l}-0.089^{* * *} \\
(0.006)\end{array}$ & $\begin{array}{l}-0.089^{* * *} \\
(0.006)\end{array}$ & $\begin{array}{l}-0.089^{\text {*** }} \\
(0.006)\end{array}$ & $\begin{array}{l}-0.089^{\text {*** }} \\
(0.006)\end{array}$ \\
\hline \multicolumn{5}{|l|}{ Likelihood that partner survives } \\
\hline Likelihood that partner survives: $60 \%$ ( $40 \%=$ ref.) & $\begin{array}{l}0.002 \\
(0.005)\end{array}$ & $\begin{array}{l}0.002 \\
(0.005)\end{array}$ & $\begin{array}{l}0.002 \\
(0.005)\end{array}$ & $\begin{array}{l}0.002 \\
(0.005)\end{array}$ \\
\hline Likelihood that partner survives: $80 \%$ & $\begin{array}{l}0.016^{* * * *} \\
(0.005)\end{array}$ & $\begin{array}{l}0.016^{* * * *} \\
(0.005)\end{array}$ & $\begin{array}{l}0.016^{* * * *} \\
(0.005)\end{array}$ & $\begin{array}{l}0.016^{* * *} \\
(0.005)\end{array}$ \\
\hline \multicolumn{5}{|l|}{ Number of years that partner survives } \\
\hline Years that partner survive: 5 ( $3=$ ref.) & $\begin{array}{l}0.011^{* *} \\
(0.005)\end{array}$ & $\begin{array}{l}0.011^{* *} \\
(0.005)\end{array}$ & $\begin{array}{l}0.012^{* *} \\
(0.005)\end{array}$ & $\begin{array}{l}0.012^{* *} \\
(0.005)\end{array}$ \\
\hline Years that partner survive: 8 & $\begin{array}{l}0.023^{* * *} \\
(0.005)\end{array}$ & $\begin{array}{l}0.022^{* * *} \\
(0.005)\end{array}$ & $\begin{array}{l}0.022^{* * *} \\
(0.005)\end{array}$ & $\begin{array}{l}0.022^{\text {**** }} \\
(0.005)\end{array}$ \\
\hline \multicolumn{5}{|l|}{ Personal Characteristics } \\
\hline Gender $($ male $=1)$ & $\begin{array}{l}0.056^{* * *} \\
(0.010)\end{array}$ & $\begin{array}{l}0.056^{* * *} \\
(0.010)\end{array}$ & $\begin{array}{l}0.057^{* * *} \\
(0.010)\end{array}$ & $\begin{array}{l}0.059^{* * *} \\
(0.010)\end{array}$ \\
\hline Age & $\begin{array}{l}0.003^{* *} \\
(0.001)\end{array}$ & $\begin{array}{l}0.003^{* *} \\
(0.001)\end{array}$ & $\begin{array}{l}0.003^{* *} \\
(0.001)\end{array}$ & $\begin{array}{l}0.003^{* *} \\
(0.001)\end{array}$ \\
\hline High education level & $\begin{array}{l}-0.017^{*} \\
(0.010)\end{array}$ & $\begin{array}{l}-0.020^{* *} \\
(0.010)\end{array}$ & $\begin{array}{l}-0.019^{* *} \\
(0.010)\end{array}$ & $\begin{array}{l}-0.021^{\text {** }} \\
(0.010)\end{array}$ \\
\hline Standardized time preferences (forward looking) & & $\begin{array}{l}0.011^{* * *} \\
(0.005)\end{array}$ & $\begin{array}{l}0.014^{* * * *} \\
(0.005)\end{array}$ & $\begin{array}{l}0.014^{* * *} \\
(0.005)\end{array}$ \\
\hline Standardized risk aversion & & & $\begin{array}{l}0.009 * * \\
(0.005)\end{array}$ & $\begin{array}{l}0.009^{* *} \\
(0.005)\end{array}$ \\
\hline Standardized altruism & & & & $\begin{array}{l}0.008^{*} \\
(0.004)\end{array}$ \\
\hline $\mathrm{N}$ & 9511 & 9511 & 9511 & 9511 \\
\hline
\end{tabular}

The table shows marginal effects. Income redistribution is measured on a 5-points scale where 1 indicates that no pension redistribution takes place and 5 means that full pension distribution takes place. The table shows the marginal effects for (5) the full pension distribution option. Clustered standard errors in parentheses. ${ }^{* * *} p<0.01,{ }^{* *} p<0.05,{ }^{*} p<0.10$.

receives a lower pension. Without redistribution after ones' death, this would imply that the surviving partner indeed loses more pension when one's own contribution to the household income was high.

When the likelihood that the partner survives is high (80\%), individuals have a significantly stronger preference for more redistribution. Columns 1 until 5 of Table 3 show that a $80 \%$ likelihood that the partner survives induces respondents $2 \%$ points less often to choose for no redistribution. Full-redistribution (outcome 5), however, is chosen $1.7 \%$-points more often by the respondents in this situation.

The expected number of surviving years by the partner also matters for pension redistribution: the preference for pension redistribution increases with the number of years the partner is expected to survive. The estimates indicate that if the partner survives eight years (compared to three years) individuals have a $2.8 \%$-points lower preference for no redistribution and a 2.3\%-points higher preference for full redistribution.

\subsection{Explaining the redistribution in pension wealth}

The preference for redistribution likely depends on personal characteristics, preferences and social attitude. In particular, a relevant question to scrutinize is to what extent gender has an impact on the decision to redistribute pension wealth to survivors' pensions. As more married women retire with increasingly substantial work experience and pension wealth in their own names it is important to get more insight into their annuitization choices compared to those of males.

Table 4 confirms that personal characteristics, preferences, and social attitude play an important role for the willingness to contribute own pension wealth to survivors' pensions. Column 1 shows the marginal effects of an ordered probit model on redistribution (marginal effects are only shown for full redistribution: outcome 5) in which we include standard per- 
sonal characteristics such as gender, age and level of education. We first observe that because of the randomization (see Table A2 in Appendix A), the successive inclusion of background characteristics does not alter the point estimates of the attributes included in the stated choice experiment. More important, however, is that the results in Column 1 show that males have a significantly stronger preference (5.6\%-points) for full redistribution compared to females. This difference even increases to 5.9\%-points when we add personality traits into our model (Column 9). A potential explanation is that this result is due to remaining traditional gender role models for this relatively old age cohort. Although gender roles are gradually changing, in particular in older cohorts, the traditional breadwinner model can still play an important role. For younger cohorts, we might expect that gender roles are substantially different, because these cohorts have become more accustomed to more equal gender roles (see, e.g., Lundberg et al., 2016).

Column 1 indeed confirms that age, even in the narrow age window of our sample, correlates significantly to stronger preferences for full pension redistribution: a 10 years increase in age is associated with a 3\%-points increase in the preference for full redistribution. Important to realize here is that due to the cross-sectional nature of our dataset, we cannot determine whether the marginal effect for age in our estimations is capturing an age or a cohort effect. In case the positive marginal effect for age reflects an age effect, most likely the demand for survivors pensions will remain high in the future. Such an age effect can be justified from the well-known fact that employees, in general, put more weight to their pension and become better informed about their pension with age. A cohort effect, however, cannot be ruled out. When our estimated relation with age represents a cohort effect, then we might indeed expect a drop in the demand for survivors pensions. This could be further amplified by the fact that more women in younger cohorts are taking part in the labor market. We also expect, however, that such a drop in the demand for survivors' pensions may be somewhat limited by the fact that even in younger cohorts women earn, on average, substantial less than their partners due to the high share of part-timers among women in the Dutch labor market. Finally, compared to intermediate and low-educated employees, high-educated employees ${ }^{16}$ prefer less full redistribution. This could potentially reflect the presence of additional income and sources of wealth that affect the way respondents make choices in the experiment.

Columns 2-4 of Table 4 successively analyze the relevance of time discounting, risk aversion, and altruism for the willingness to redistribute pension wealth to survivors' pensions. Time preferences and risk aversion are economic preferences, which have shown to be fundamental determinants of decision making in economic models. Their importance is confirmed by studies showing that individual differences in risk aversion and impatience predict a wide range of important economic outcomes (e.g., Guiso and Paiella 2008; Eckel et al., 2005). With respect to pension savings, intertemporal economic choice models conjecture that individuals formulate assumptions about their lifetime resources and make consumption decisions on these anticipated resources, rather than simply base their decision on the available current income. Smoothing consumption over their own lifetime and their survivor will indeed require a forward-looking perspective. We would therefore expect that more forward-looking respondents are more willing to redistribute part of their pension wealth to their survivor's pension. Similarly, we would also expect that more risk averse employees are more willing to redistribute pension wealth in favor of a survivor's pension. Barsky et al. (1997) showed that risk aversion has predictive power for choices over a number of risky behaviors, including the decisions to smoke or drink as well as to hold stocks or to take out insurance. Brown (2001) further confirmed that household decisions about whether or not to annuitize retirement resources are positively related to risk aversion.

Moreover, it is rather intuitive to conjecture that more altruistic individuals are willing to give more to their spouse, and, hence, are also more willing to redistribute their pension income to a survivor's pension. Various economic studies have expressed altruism in terms of one person including another person's consumption in his or her utility function (e.g. Becker (1974) on love and caring between husband and wife and Becker (1981) on altruism). And several studies have found that altruism is indeed a major driver of bequest motives (e.g., Laitner and Juster, 1996; Laitner and Ohlsson, 2001).

Table 4 shows that forward looking individuals have a significantly stronger preference for full redistribution of pension income to the survivor's pension: a one standard deviation increase in time preference results in a $2.2 \%$-points higher preference for full redistribution (Column 2). This even increases to 2.8\%-points when we control for risk preferences and altruism (Columns 3 and 4). This is an economically significant effect as it has a larger size to that of an increase in the survival probability of the spouse from $40 \%$ to $80 \%$.

Both risk preferences and altruism are also significantly and positively related to the preference for full redistribution. The marginal effects ( 0.009 for risk preferences and 0.008 for altruism) are, however, smaller than the marginal effect for time preference. Interestingly, the inclusion of time preference, risk preference, and altruism do not affect the marginal effects of the other personal characteristics. In particular, the stronger preference for full pension redistribution among males compared to females cannot be explained by underlying differences in economic preferences or social attitudes.

\subsection{Interaction stated preferences experiment conditions with personal characteristics}

Individuals' personal characteristics can matter for how they consider the relevance of various attributes of the stated preference experiment when making their pension redistribution decision. We have therefore run split-sample ordered probit models on redistribution (we present only the marginal effects for full redistribution: outcome 5) to test the extent to

\footnotetext{
${ }^{16}$ University of applied science or higher.
} 
Table 5

Explaining pension redistribution: interaction vignette items and personal characteristics.

\begin{tabular}{|c|c|c|c|c|c|}
\hline $\begin{array}{l}\text { Ordered probit: Marginal effects of the predicted probability for } \\
\text { the largest redistribution }\end{array}$ & (1) & Women & $\begin{array}{l}\text { (3) } \\
\text { SD Time } \\
\text { preferences } \\
\text { score }<-1.3\end{array}$ & $\begin{array}{l}(4) \\
\text { SD Time } \\
\text { preferences } \\
\text { score }>-1.3 \\
\text { and }<0.58\end{array}$ & $\begin{array}{l}(5) \\
\text { SD Time } \\
\text { preferences } \\
\text { score }>0.58\end{array}$ \\
\hline \multicolumn{6}{|l|}{ Vignette characteristics } \\
\hline $\begin{array}{l}\text { Family Income during working life }=6250 \text { (low income } \\
(5000)=\text { ref.) } \\
\text { Family Income during working life }=7500\end{array}$ & $\begin{array}{l}0.003 \\
(0.006) \\
0.008 \\
(0.006)\end{array}$ & $\begin{array}{l}-0.005 \\
(0.006) \\
-0.004 \\
(0.006)\end{array}$ & $\begin{array}{l}0.040^{*} \\
(0.024) \\
0.007 \\
(0.023)\end{array}$ & $\begin{array}{l}0.004 \\
(0.006) \\
0.000 \\
(0.007)\end{array}$ & $\begin{array}{l}-0.016^{* *} \\
(0.008) \\
-0.001 \\
(0.007)\end{array}$ \\
\hline \multicolumn{6}{|l|}{ Contribution to family income during working life } \\
\hline $75 \%$ oneself and $25 \%$ partner $(100 \%$ oneself $=$ ref. $)$ & $\begin{array}{l}0.008 \\
(0.009)\end{array}$ & $\begin{array}{l}0.006 \\
(0.007)\end{array}$ & $\begin{array}{l}0.014 \\
(0.024)\end{array}$ & $\begin{array}{l}0.005 \\
(0.008)\end{array}$ & $\begin{array}{l}0.009 \\
(0.009)\end{array}$ \\
\hline $50 \%$ oneself and $50 \%$ partner & $\begin{array}{l}-0.043^{* * *} \\
(0.008)\end{array}$ & $\begin{array}{l}-0.073^{* * *} \\
(0.007)\end{array}$ & $\begin{array}{l}-0.050^{* *} \\
(0.025)\end{array}$ & $\begin{array}{l}-0.072^{* * *} \\
(0.008)\end{array}$ & $\begin{array}{l}-0.066^{* * *} \\
(0.008)\end{array}$ \\
\hline $25 \%$ oneself and $75 \%$ partner & $\begin{array}{l}-0.063^{* * *} \\
(0.010)\end{array}$ & $\begin{array}{l}-0.091^{* * *} \\
(0.007)\end{array}$ & $\begin{array}{l}-0.049^{*} \\
(0.027)\end{array}$ & $\begin{array}{l}-0.088^{\text {*** }} \\
(0.009)\end{array}$ & $\begin{array}{l}-0.096^{* * *} \\
(0.009)\end{array}$ \\
\hline \multicolumn{6}{|l|}{ Likelihood that partner survives } \\
\hline Likelihood that partner survives: $60 \%$ ( $40 \%=$ ref.) & $\begin{array}{l}0.006 \\
(0.006)\end{array}$ & $\begin{array}{l}-0.000 \\
(0.006)\end{array}$ & $\begin{array}{l}-0.034 \\
(0.028)\end{array}$ & $\begin{array}{l}0.002 \\
(0.006)\end{array}$ & $\begin{array}{l}0.009 \\
(0.007)\end{array}$ \\
\hline Likelihood that partner survives: $80 \%$ & $\begin{array}{l}0.008 \\
(0.006)\end{array}$ & $\begin{array}{l}0.017^{* * * *} \\
(0.006)\end{array}$ & $\begin{array}{l}-0.033 \\
(0.028)\end{array}$ & $\begin{array}{l}0.016^{* *} \\
(0.006)\end{array}$ & $\begin{array}{l}0.024^{* * *} \\
(0.008)\end{array}$ \\
\hline \multicolumn{6}{|l|}{ Number of years that partner survives } \\
\hline Years that partner survive: 5 ( $3=$ ref.) & $\begin{array}{l}0.006 \\
(0.006)\end{array}$ & $\begin{array}{l}0.013^{* *} \\
(0.006)\end{array}$ & $\begin{array}{l}0.023 \\
(0.023)\end{array}$ & $\begin{array}{l}0.008 \\
(0.006)\end{array}$ & $\begin{array}{l}0.012 * \\
(0.007)\end{array}$ \\
\hline Years that partner survive: 8 & $\begin{array}{l}0.007 \\
(0.006)\end{array}$ & $\begin{array}{l}0.027^{* * *} \\
(0.006)\end{array}$ & $\begin{array}{l}0.007 \\
(0.020)\end{array}$ & $\begin{array}{l}0.020^{* * * *} \\
(0.006)\end{array}$ & $\begin{array}{l}0.027^{* * * *} \\
(0.008)\end{array}$ \\
\hline \multicolumn{6}{|l|}{ Personal Characteristics } \\
\hline Gender $($ male $=1)$ & & & $\begin{array}{l}0.002 \\
(0.006)\end{array}$ & $\begin{array}{l}0.003 \\
(0.002)\end{array}$ & $\begin{array}{l}0.003 \\
(0.002)\end{array}$ \\
\hline Age & $\begin{array}{l}0.002 \\
(0.002)\end{array}$ & $\begin{array}{l}0.003^{*} \\
(0.002)\end{array}$ & $\begin{array}{l}-0.055 \\
(0.039)\end{array}$ & $\begin{array}{c}-0.014 \\
(0.012)\end{array}$ & $\begin{array}{l}-0.019 \\
(0.016)\end{array}$ \\
\hline High education level & $\begin{array}{l}-0.025^{*} \\
(0.014)\end{array}$ & $\begin{array}{l}-0.018 \\
(0.012)\end{array}$ & $\begin{array}{l}0.095^{*} \\
(0.055)\end{array}$ & $\begin{array}{l}0.043^{* * *} \\
(0.013)\end{array}$ & $\begin{array}{l}0.072^{* * *} \\
(0.017)\end{array}$ \\
\hline Standardized time preferences (forward looking) & $\begin{array}{l}0.011 \\
(0.007)\end{array}$ & $\begin{array}{l}0.014^{* *} \\
(0.006)\end{array}$ & & & \\
\hline Standardized risk aversion & $\begin{array}{l}0.004 \\
(0.006)\end{array}$ & $\begin{array}{l}0.011^{*} \\
(0.006)\end{array}$ & $\begin{array}{l}0.057^{* * * *} \\
(0.019)\end{array}$ & $\begin{array}{l}0.002 \\
(0.006)\end{array}$ & $\begin{array}{l}0.008 \\
(0.007)\end{array}$ \\
\hline Standardized altruism & $\begin{array}{l}0.002 \\
(0.004)\end{array}$ & $\begin{array}{l}0.010^{*} \\
(0.005)\end{array}$ & $\begin{array}{l}0.029^{* * *} \\
(0.011)\end{array}$ & $\begin{array}{l}0.005 \\
(0.006)\end{array}$ & $\begin{array}{l}0.006 \\
(0.006)\end{array}$ \\
\hline$N$ & 2030 & 7481 & 698 & 4682 & 4131 \\
\hline
\end{tabular}

The table shows the marginal effects of separate analyses for women and men, and for respondents with the three lowest scores (score of SD time preferences $<-1.3$ ), intermediate scores (score of SD time preferences $>-1.3$ and $<0.58$ ), and the three highest scores on the 11 -itemes time preferences scale (score of SD time preferences 0.58). The marginal effects in the table shows the marginal effects for (5) the full pension distribution option. Clustered standard errors in parentheses. ${ }^{* * *} p<0.01,{ }^{* *} p<0.05,{ }^{*} p<0.10$

which our basic results differ depending on respondents' personal characteristics. We run, among others, separate analyses by gender, education and age groups, and for time preference, risk aversion and altruism where we split respondents into three groups with low, intermediate and high score on these characteristics. We find significant heterogeneities by gender and for time preference (split-sample analyses are reported in Table 5) but not for other personal characteristics (results for the other personal characteristics are available on request). In order to get a better grip on the heterogeneous effects by gender and time preference, we plot the marginal effects in Fig. 2 (by gender) and Fig. 3 (for time preference). These marginal effects are calculated from a fully interacted ordered probit models for redistribution (again we report the results for full redistribution; outcome 5) in which gender and time preference are interacted with all attributes in the experiment.

We find that compared to women, men are more inclined to fully redistribute to their spouse's survival pension even when their own contribution during working life is only $25 \%$ of the total household income (Columns 1 and 2 of Table 5). This is best seen in Fig. 2 that plots the gender interaction with the contribution to family income for the full redistribution outcome. The gap between men and women significantly widens when individuals contributes during working life only $25 \%$ of the total household income. This is again an indication of stronger redistributive preferences among males.

We further find that when the respondent's contribution to the family income equals $25 \%$ of total income, a strong future orientation is negatively associated with full redistribution (Columns 3-5 of Table 5). This compensates for the positive 


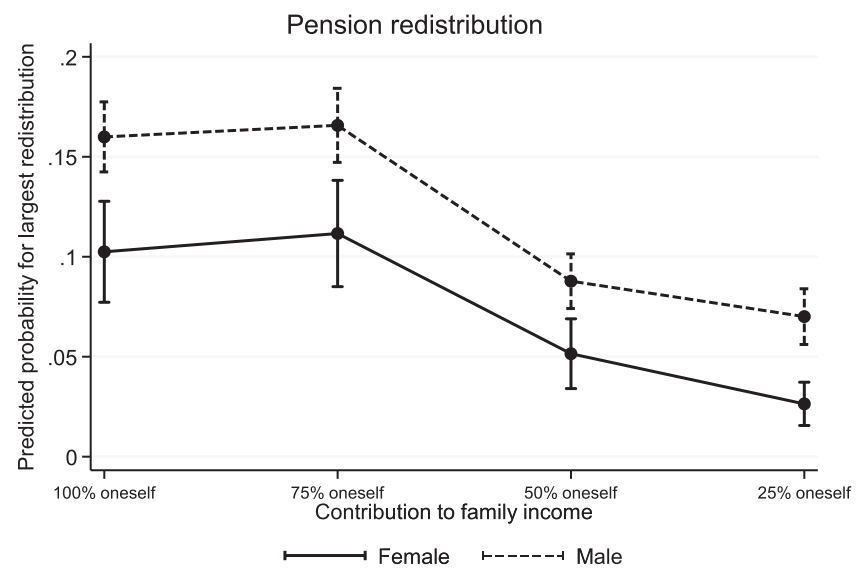

Fig. 2. Plotted marginal effects on pension redistribution by the contribution to family income and gender (based on Table 5).

Fig. 2 plots the marginal effects of a fully interacted ordered probit model redistribution (results show for full redistribution, outcome 5) in which each of the personal characteristics included in Table 4 is interacted to the various attributes in the experiment. The figure shows the marginal effects of the interaction term between contribution to family income ( $x$-axis) and gender on the predicted probability for full redistribution.

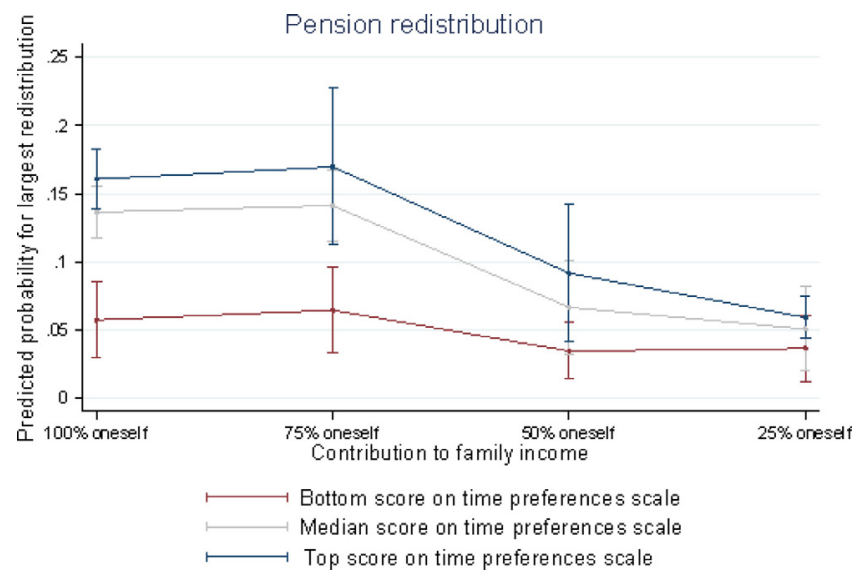

Fig. 3. Plotted marginal effects on pension redistribution by the contribution to family income and time preferences (based on Table 5).

Fig. 3 plots the marginal effects of a fully interacted ordered probit model on redistribution (results show for full redistribution, outcome 5) in which each of the personal characteristics included in Table 4 is interacted to the various attributes in the experiment. The figure shows the marginal effects of the interaction term between contribution to family income ( $x$-axis) and different scores on the time preferences scale on the predicted probability for full redistribution. We distinguish between the bottom score (including the three lowest scores on the time preferences scale, a top score (including the highest three scores on the time preferences scale), and an intermediate score (including all scores between the bottom and top three scores of the time preferences scale).

effect of time preferences on pension redistribution. Overall, the differences in preferences for full pension redistribution are not statistically significant for those who differ in their time preference when their own contribution to family income is only $25 \%$, while this is the case when they contribute more than $25 \%$ (see Fig. 3). The figure thus shows that the gradient in the preferences for full redistribution is steeper for those who are strongly forward looking: their preference for full redistribution declines faster with decreasing shares of their own contribution to family income, possibly because of considerations of having a too low pension income themselves while they are still alive.

\subsection{Perception of partners' economic preferences}

If partners decide on the redistribution of pension income, we can expect that they consider their partners' preferences. The economic preferences of the partner may than have an effect on the redistribution outcomes independent of the impact of the economic preferences of the respondent. Raw correlations between the economic preferences of the respondents and the perception of their partner's economic preferences indicates that this may be the case. These correlations are relatively 
Table 6

Explaining pension redistribution: partner characteristics.

\begin{tabular}{|c|c|}
\hline $\begin{array}{l}\text { Ordered probit: Marginal effects of the predicted probability for the largest } \\
\text { redistribution }\end{array}$ & (1) \\
\hline \multicolumn{2}{|l|}{ Vignette characteristics } \\
\hline \multicolumn{2}{|l|}{ Family income during working life } \\
\hline Family Income during working life $=6250$ (low income $(5000)=$ ref.) & $\begin{array}{l}-0.002 \\
(0.005)\end{array}$ \\
\hline Family Income during working life $=7500$ & $\begin{array}{l}-0.001 \\
(0.005)\end{array}$ \\
\hline \multicolumn{2}{|l|}{ Contribution to family income during working life } \\
\hline $75 \%$ oneself and $25 \%$ partner $(100 \%$ oneself $=$ ref. $)$ & $\begin{array}{l}0.006 \\
(0.006)\end{array}$ \\
\hline $50 \%$ oneself and $50 \%$ partner & $\begin{array}{l}-0.068^{* * *} \\
(0.006)\end{array}$ \\
\hline $25 \%$ oneself and $75 \%$ partner & $\begin{array}{l}-0.089^{* * *} \\
(0.006)\end{array}$ \\
\hline \multicolumn{2}{|l|}{ Likelihood that partner survives } \\
\hline Likelihood that partner survives: $60 \%(40 \%=$ ref.) & $\begin{array}{l}0.002 \\
(0.005)\end{array}$ \\
\hline Likelihood that partner survives: $80 \%$ & $\begin{array}{l}0.017^{* * * *} \\
(0.005)\end{array}$ \\
\hline \multicolumn{2}{|l|}{ Number of years that partner survives } \\
\hline Years that partner survive: 5 ( 3 =ref.) & $\begin{array}{l}0.012^{* *} \\
(0.005)\end{array}$ \\
\hline Years that partner survive: 8 & $\begin{array}{l}0.022^{* * *} \\
(0.005)\end{array}$ \\
\hline \multicolumn{2}{|l|}{ Personal characteristics } \\
\hline Gender $($ male $=1)$ & $\begin{array}{l}0.055^{* * *} \\
(0.012)\end{array}$ \\
\hline Age & $\begin{array}{l}0.004^{* *} \\
(0.002)\end{array}$ \\
\hline High education level & $\begin{array}{l}-0.018^{*} \\
(0.011)\end{array}$ \\
\hline Standardized time preferences (forward looking) & $\begin{array}{l}0.009^{*} \\
(0.006)\end{array}$ \\
\hline Standardized risk aversion & $\begin{array}{l}0.010^{*} \\
(0.005)\end{array}$ \\
\hline Standardized altruism & $\begin{array}{l}0.006 \\
(0.004)\end{array}$ \\
\hline \multicolumn{2}{|l|}{ Partner characteristics } \\
\hline Age & $\begin{array}{l}-0.001 \\
(0.001)\end{array}$ \\
\hline High education level partner & $\begin{array}{l}-0.008 \\
(0.009)\end{array}$ \\
\hline Standardized time preferences partner (forward looking) & $\begin{array}{l}0.010^{* *} \\
(0.005)\end{array}$ \\
\hline Standardized risk aversion partner & $\begin{array}{l}-0.000 \\
(0.005)\end{array}$ \\
\hline Standardized altruism partner & $\begin{array}{l}0.003 \\
(0.005)\end{array}$ \\
\hline Observations & 9383 \\
\hline
\end{tabular}

The table shows marginal effects. Income redistribution is measured on a 5-points scale where 1 indicates that no pension redistribution takes place and 5 means that full pension distribution takes place. The table shows the marginal effects for (5) the full pension distribution option. Clustered standard errors in parentheses. ${ }^{* * *} p<0.01,{ }^{* *} p<0.05$, * $p<0.10$.

small: 0.473 for time preferences, 0.480 for risk aversion, and 0.331 for altruism, implying that the perceptions of partner's economic preferences are indeed measuring something different than one's own economic preferences. Table 6 reports the marginal effects from an ordered probit model on redistribution (results shown for full redistribution, outcome 5) in which we next to the respondent's own economic preferences include the perceptions of the economic preferences of their partner. The table shows that the size of the marginal effects of respondent's own economic preferences remains roughly the same when we include their perceptions of their spouse's economic preferences. Only the size of the marginal effect of the time preferences decreases to 0.009 , but remains significant at the $10 \%$-level. Furthermore, the marginal effect for altruism becomes statistically insignificant. However, the marginal effect was only significant at the $10 \%$-level in Table 4 . Most interestingly, however, is that we observe a statistically significant marginal effect for the time preference of the partner of 0.010 , which implies that the forward looking behavior of the partner might be as important for the decision to redistribute pension income to the partner than the respondent's own income. Although this result should be interpreted cautiously due 
Table 7

Basic model with attributes in experiment: privatized sector.

\begin{tabular}{|c|c|}
\hline Ordered probit: Marginal effects of the predicted probability for the largest redistribution & (1) \\
\hline \multicolumn{2}{|l|}{ Family income during working life } \\
\hline Family Income during working life $=6250$ (low income $(5000)=$ ref.) & $\begin{array}{l}-0.014 \\
(0.016)\end{array}$ \\
\hline Family Income during working life $=7500$ & $\begin{array}{l}-0.029^{*} \\
(0.015)\end{array}$ \\
\hline \multicolumn{2}{|l|}{ Contribution to family income during working life } \\
\hline $75 \%$ oneself and $25 \%$ partner $(100 \%$ oneself $=$ ref. $)$ & $\begin{array}{l}-0.008 \\
(0.017)\end{array}$ \\
\hline $50 \%$ oneself and $50 \%$ partner & $\begin{array}{l}-0.082^{* * *} \\
(0.019)\end{array}$ \\
\hline $25 \%$ oneself and $75 \%$ partner & $\begin{array}{l}-0.116^{* * *} \\
(0.018)\end{array}$ \\
\hline \multicolumn{2}{|l|}{ Likelihood that partner survives } \\
\hline Likelihood that partner survives: $60 \%(40 \%=$ ref.) & $\begin{array}{l}-0.009 \\
(0.016)\end{array}$ \\
\hline Likelihood that partner survives: $80 \%$ & $\begin{array}{l}0.018 \\
(0.018)\end{array}$ \\
\hline \multicolumn{2}{|l|}{ Number of years that partner survives } \\
\hline Years that partner survive: 5 ( $3=$ ref.) & $\begin{array}{l}0.053^{* * * *} \\
(0.015)\end{array}$ \\
\hline Years that partner survive: 8 & $\begin{array}{l}0.026^{*} \\
(0.014)\end{array}$ \\
\hline Observations & 1276 \\
\hline
\end{tabular}

The table shows marginal effects. Income redistribution is measured on a 5-points scale where 1 indicates that no pension redistribution takes place and 5 means that full pension distribution takes place. The table shows the marginal effects for (5) the full pension distribution option. Clustered standard errors in parentheses. ${ }^{* * *} p<0.01,{ }^{* *} p<0.05$, * $p<0.10$.

to potential measurement problems, it is consistent with recent literature that emphasizes the importance of the bargaining and joint decision process between spouses for retirement and savings decisions(e.g., Lundberg et al., 2003; Shuey 2004; Lalive and Parrotta, 2017).

\section{Robustness checks}

\subsection{Public sector employees vs privatized sector employees}

The sample is specific as its focuses on public sector employees. The question is whether our results are generalizable to employees outside the public sector. As research shows, public sector employees tend to be more risk averse and altruistic than private sector employees and they also are more highly educated. This might affect the chosen pension redistribution in our stated preferences experiment and deserves attention. ${ }^{17}$

Important in this context is the study of Buurman et al. (2012) who used data from a questionnaire held in 2000 covering more than 2.600 employees in The Netherlands to assess whether public sector employees have a stronger inclination to serve others and are more risk averse than employees in the private sector. Most interestingly, they showed that Dutch public sector employees indeed tend to be more risk averse and altruistic than private sector employees, but also that these differences in risk aversion and altruism disappear with tenure. Since we only include employees aged 55 years or older in our estimation sample, the latter would imply that behavioral differences between private and public sector employees with regard to pension redistribution might be rather small.

Since ABP also serves the privatized sector (among others water energy and utilities, transport companies, telecom companies, etc.), we are also able to test more formally whether results differ between employees in the public and the private sectors. The companies in the privatized sector have been privatized already 20-25 years ago and, arguably, behavioral attitudes of employees in these organizations should therefore be much closer to the private sector.

\footnotetext{
17 Differences in pension arrangements and pension information between the private and public sector in the Netherlands are limited. Although each occupational pension scheme has its specific pension arrangements, the most common occupational pension schemes are based on the average salary an employee has built up during their entire career. These average-salary schemes have almost totally replaced the older final salary schemes, based on employees' last salary. Most common are DB (defined benefit) schemes, although other types are growing in popularity. It is also important to note that all pension schemes are negotiated by the social partners (employer organizations (among which those in the public sector (such as the Association of Dutch Universities and the supporting employer organization AWVN) and unions). As the employer organizations and unions are organized nationwide (and cover many sectors), there are many spillovers during these negotiations, implying that differences between occupational pension schemes are relatively small.
} 
Table 8

Basic model with attributes in experiment: excluding 50\% redistribution.

\begin{tabular}{|c|c|}
\hline Ordered probit: Marginal effects of the predicted probability for the largest redistribution & $(1)$ \\
\hline \multicolumn{2}{|l|}{ Family income during working life } \\
\hline Family Income during working life $=6250$ (low income $(5000)=$ ref.) & $\begin{array}{l}-0.003 \\
(0.008)\end{array}$ \\
\hline Family Income during working life $=7500$ & $\begin{array}{l}0.002 \\
(0.008)\end{array}$ \\
\hline \multicolumn{2}{|l|}{ Contribution to family income during working life } \\
\hline $75 \%$ oneself and $25 \%$ partner ( $100 \%$ oneself $=$ ref.) & $\begin{array}{l}0.013 \\
(0.010)\end{array}$ \\
\hline $50 \%$ oneself and $50 \%$ partner & $\begin{array}{l}-0.110^{\text {**** }} \\
(0.010)\end{array}$ \\
\hline $25 \%$ oneself and $75 \%$ partner & $\begin{array}{l}-0.141^{\text {***** }} \\
(0.011)\end{array}$ \\
\hline \multicolumn{2}{|l|}{ Likelihood that partner survives } \\
\hline Likelihood that partner survives: $60 \%$ (40\%=ref.) & $\begin{array}{l}0.002 \\
(0.008)\end{array}$ \\
\hline Likelihood that partner survives: $80 \%$ & $\begin{array}{l}0.024^{* * *} \\
(0.009)\end{array}$ \\
\hline \multicolumn{2}{|l|}{ Number of years that partner survives } \\
\hline Years that partner survive: 5 ( $3=$ ref.) & $\begin{array}{l}0.020^{* *} \\
(0.008)\end{array}$ \\
\hline Years that partner survive: 8 & $\begin{array}{l}0.035^{* * *} \\
(0.008)\end{array}$ \\
\hline Observations & 6133 \\
\hline
\end{tabular}

The table shows marginal effects. Income redistribution is measured on a 5-points scale where 1 indicates that no pension redistribution takes place and 5 means that full pension distribution takes place. The table shows the marginal effects for (5) the full pension distribution option. Clustered standard errors in parentheses. ${ }^{* * *} p<0.01,{ }^{* *} p<0.05$, $* p<0.10$.

Table 7 shows the marginal effects of ordered probit estimates on redistribution (results show for full redistribution, outcome 5) for employees in the privatized sector. The table shows that the marginal effects of the ordered probit estimates of employees in the privatized sector are close to those for the public sector presented in Table 3 . The marginal effects of the contribution of the family income as well as the number of years that the partner survives remain statistically significant. The family income during life has also no strong significant impact on the redistribution of employees in the privatized sector. The main difference is that we do not observe a significant effect of the likelihood that the partner survives. However, the size of the marginal effects is close to those for the public sector employees. Hence, we might expect that our results are likely to hold for private sector employees.

\subsection{Excluding 50\% redistribution}

As mentioned earlier, the peak at $50 \%$ redistribution is a potential concern as it could reflect that respondents do not understand the vignette and choose $50 \%$ as a safe option in the middle of the scale. Although we already mentioned that only $6 \%$ choose for $50 \%$ redistribution in all 6 vignette rounds, we pursue this issue further by performing an additional robustness check in which we removed all observations in which respondents chose a 50\% redistribution. Table 8 reports the results of this robustness analysis and shows that our main findings are robust to this exclusion.

\section{Conclusion}

This paper uses a stated-preferences approach to estimate the willingness of Dutch public sector employees to redistribute their own pension wealth to increase the survivor pension of their partner after their death. We find that total family income during working life does not affect the redistribution of respondents' pension wealth to the survivor pension of their spouse. However, the relative contribution to total family income before retirement of both partners, as well as the survival likelihood of the partner and the number of years the partner is expected to survive, do have a significant impact on the redistribution in favor of the survivor's pension. Although our analyses cover public sector employees, our robustness check on employees in the privatized sector suggest that our results are likely to hold for private sector employees too.

The redistribution to survivor pensions also depends on personal characteristics, preferences and social attitude. Males have a significantly stronger preference for redistribution compared to females. Moreover, forward-looking, more risk averse and more altruistic individuals have a stronger preference to redistribute part of their pension wealth to a survivor's pension. Finally, when employees perceive that their partner is forward looking, they also redistribute more of their pension wealth to the survivor pension of their spouse. 
This study adds to the literature on survivors' pensions in multiple ways. First, we use recent data that better fit into the current legal, social, and economic environment and are closer related to the European context so that we get more reliable insights in the importance of survivors' pensions after the retrenchment of pension wealth due to the pension reforms that took place in many developed countries. Second, the stated-preferences approach allows us to elicit more accurately the true preferences for survivor's protection than previous studies. Third, the randomization of the key conditions in the vignettes allows us to make causal claims about the relative importance of the monthly family income during working life, the relative contribution to family income of both partners during working life, the survival probability of the partner, and the duration of the survival of the partner for the redistribution of pension wealth to the surviving partner. Fourth, we consider the survivor pension decisions of women, which have been largely ignored in previous studies. Finally, we go beyond other studies by showing that survivor pension investments in the Netherlands strongly depend on time preferences, risk preferences, and altruism as well as the economic preferences of partners.

From our results, we can conclude that the demand for survivor's pensions is currently most likely higher than revealed preferences data suggest. It is therefore vital for policy makers, pension funds and insurance companies to be aware that, due to the lacking transparency in the communication on and knowledge of survivors' pensions, as well as the lack of transparent products and choice architecture, true preferences for survivor's protection may be much stronger than current revealed preferences show. Therefore, it is important to improve the knowledge of particularly those who will retire in the coming years on the survivor pension options that are present in the current pension schemes. The fact that economic preferences of both partners matter, indicates further that communication plans should not focus on the individual level, but should be targeted to households in general.

\section{Appendix A}

\section{Pension redistribution preferences}

Imagine that you are a person who lives together with a partner who is the same age as yourself. The gross family income before you retire is $\mathbf{5 0 0 0}$ euro per month. Your salary is $\mathbf{5 0 0 0}$ euros before retirement, and your partner earns 0 euros. You are both retiring at the age of 67 . You and your partner do not have any equity or debt and will not have any other income besides the pension. In the event that you do not arrange for a survivor's pension for your partner, you will receive a joint pension of $\mathbf{3 5 0 0}$ euros up to your death (including AOW). If you die earlier than your partner does, your partner will only receive his / her own pension during the rest of his / her life (minimum pension amount is the AOW). However, it is possible that you give your partner a higher pension if you die. You can do this by redistributing part of your pension during your life against a higher pension of your partner after your death. Imagine that the probability is very high (about $\mathbf{8 0} \%$ ) that your partner survives for at least $\mathbf{3}$ years, which of the redistribution options below would you choose?

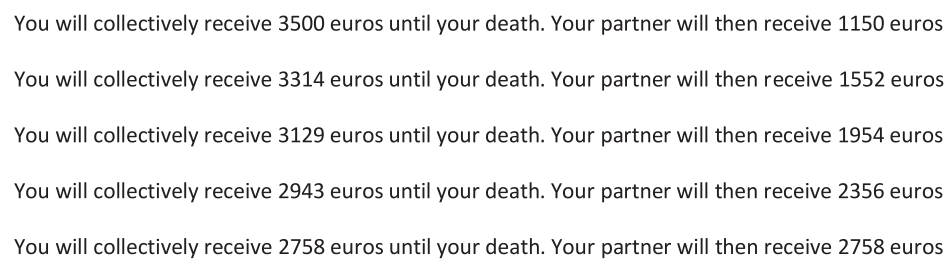

Fig. A1. Screen shot stated preferences vignette. 
Table A1

Stylistic examples. Stated preferences scenarios, corresponding pensions, and redistributive choice options.

\begin{tabular}{|c|c|c|}
\hline \multicolumn{3}{|c|}{ Examples scenarios and redistributive choice options } \\
\hline \multirow{2}{*}{\multicolumn{3}{|c|}{ Scenario 1}} \\
\hline & & \\
\hline & Household income/corresponding pension when both partners are alive without redistribution & : 7500 euro / 5250 euro \\
\hline & Contribution to family income during working life & : $100 \%$ oneself $-0 \%$ partner \\
\hline & Likelihood that partner survives & $: 40 \%$ \\
\hline & Duration survival partner & : 8 years \\
\hline & Redistributive choice options & \\
\hline & Joint pension of 5250 euro until own death, partner receives 1150 euro afterwards & \\
\hline & Joint pension of 4926 euro until own death, partner receives 1851 euro afterwards & \\
\hline & Joint pension of 4603 euro until own death, partner receives 2553 euro afterwards & \\
\hline & Joint pension of 4279 euro until own death, partner receives 3254 euro afterwards & \\
\hline & Joint pension of 3955 euro until own death, partner receives 3955 euro afterwards & \\
\hline \multirow[t]{12}{*}{ Scenario 2} & & \\
\hline & Dimensions & \\
\hline & Household income / corresponding pension when both partners are alive without redistribution & 5000 euro / 3500 euro \\
\hline & Contribution to family income during working life & $25 \%$ oneself $-75 \%$ partner \\
\hline & Likelihood that partner survives & $80 \%$ \\
\hline & Duration survival partner & 3 years \\
\hline & Redistributive choice options & \\
\hline & Joint pension of 3500 euro until own death, partner receives 2625 euro afterwards & \\
\hline & Joint pension of 3431 euro until own death, partner receives 2775 euro afterwards & \\
\hline & Joint pension of 3362 euro until own death, partner receives 2924 euro afterwards & \\
\hline & Joint pension of 3293 euro until own death, partner receives 3074 euro afterwards & \\
\hline & Joint pension of 3224 euro until own death, partner receives 3224 euro afterwards & \\
\hline
\end{tabular}

Table A2

Randomization check of conditions in stated preferences experiment.

\begin{tabular}{ll}
\hline Characteristic & Percentage \\
\hline Family income & \\
3500 & 32.41 \\
6250 & 33.69 \\
7500 & 33.90 \\
Contribution to family income & \\
$100 \%$ oneself - 0\% partner & 25.1425 .71 \\
$75 \%$ oneself - 25\% partner & 25.71 \\
$50 \%$ oneself - 25\% partner & 24.41 \\
$25 \%$ oneself-75\% partner & 24.74 \\
Survival probability partner & \\
$40 \%$ & 33.41 \\
$60 \%$ & 33.19 \\
$80 \%$ & 33.39 \\
Survival duration & \\
3 years & 33.18 \\
5 years & 32.95 \\
8 years & 33.87 \\
\hline
\end{tabular}

\section{References}

Altonji, J.G., Hayashi, F., Kotlikoff, L.J., 1992. Is the extended family altruistically linked? Direct tests using micro data. Am. Econ. Rev. 1177-1198.

Barsky, R.B., Juster, F.T., Kimball, M.S., Shapiro, M.D., 1997. Preference parameters and behavioral heterogeneity: an experimental approach in the health and retirement study. Q. J. Econ. 112, 537-579.

Becker, G.S., 1974. A theory of social interactions. J. Polit. Econ. 82 (61), 1063-1093.

Becker, G.S., 1981. A Treatise on the Family, first ed. Harvard University Press, Cambridge, MA.

Benjamin, D.J., Heffetz, O., Kimball, M., Szembrot, N., 2014. Beyond happiness and satisfaction: toward well-being indices based on stated preference. Am. Econ. Rev. 104 (9), 2698-2735.

Börsch-Supan, A.H., 2012. Entitlement reforms in Europe: policy mixes in the current pension reform process. National Bureau of Economic Research Working Paper 18009 .

Boskin, M.J., Kotlikoff, L.J., 1985. Pubic Debt and US Saving: A New Test of the Neutrality Hypothesis.

Braga, J., Humphrey, S.J., Starmer, C., 2009. Market experience eliminates some anomalies-and creates new ones. Eur. Econ. Rev. 53 (4), $401-416$.

Brown, J.R., 2001. Private pensions, mortality risk, and the decision to annuitize. J. Public Econ. 82 (1), 29-62.

Brown, J.R., Poterba, J.M., 2000. Joint life annuities and annuity demand by married couples. J. Risk Insurance 67, 527-553.

Browning, M., 2000. The saving behaviour of a two-person household. Scand. J. Econ. 102 (2), 235-251.

Buurman, M., Delfgaauw, J., Dur, R., Van den Bossche, S., 2012. Public sector employees: risk averse and altruistic? J. Econ. Behav. Organ. 83 (3), 279-291.

Chiappori, P., 1988. Rational household labor supply. Econometrica 56, 63-89.

Chiappori, P., 1992. Collective labor supply and welfare. J. Polit. Econ. 100, 437-467.

De Grip, A., Lindeboom, M., Montizaan, R., 2012. Shattered dreams: the effects of changing the pension system late in the game. Econ. J. 122 (559), 1-25. 
De Grip, A., Fouarge, D., Montizaan, R., 2013. How sensitive are individual retirement expectations to raising the retirement age? De Economist 161 (3), $225-251$.

Dohmen, T., Falk, A., Huffman, D., Sunde, U., Schupp, J., Wagner, G.G., 2011. Individual risk attitudes: measurement, determinants, and behavioral consequences. J. Eur. Econ. Assoc. 9 (3), 522-550.

Donni, O., Chiappori, P.A., 2011. Nonunitary models of household behavior: a survey of the literature. In: Household Economic Behaviors. Springer, New York, NY, pp. 1-40.

Duval, R., 2005. The retirement effect of old-age pension and early retirement schemes in OECD countries. Economic Policy Reforms 2005: Going for Growth. OECD Publishing, Paris.

Eckel, C., Johnson, C., Montmarquette, C., 2005. Saving decisions of the working poor: short-and long-term horizons. In: Field Experiments in Economics. Emerald Group Publishing Limited, pp. 219-260.

Eggers, A.C., Fowler, A., Hainmueller, J., Hall, A.B., Snyder Jr., J.M., 2015. On the validity of the regression discontinuity design for estimating electoral effects: new evidence from over 40,000 close races. Am. J. Pol. Sci. 59 (1), 259-274.

Eifler, S., 2007. Evaluating the validity of self-reported deviant behavior using vignette analyses. Qual. Quant. 41, 303-318.

Elsayed, A., de Grip, A., Fouarge, D., Montizaan, R., 2018. Gradual retirement, financial incentives, and labour supply of older workers: evidence from a stated preference analysis. J. Econ. Behav. Organ. 150, 277-294.

Eurostat, 2017. Survivors' Benefits in the EU https://ec.europa.eu/eurostat/web/products-eurostat-news/-/EDN-20170622-1?inheritRedirect=true.

Falk, A., Becker, A., Dohmen, T., Enke, B., Huffman, D., Sunde, U., 2018. Global evidence on economic preferences. Q.J. Econ 133 (4), 1645-1692.

Fehr, H., Habermann, C., Kindermann, F., 2008. Social security with rational and hyperbolic consumers. Rev. Econ. Dyn. 11 (4), $884-903$.

Fehr, H., Kallweit, M., Kindermann, F., 2017. Families and social security. Eur. Econ. Rev. 91, 30-56.

Frericks, P., Hoeppner, J., 2018. What about family in European old-age security systems? The complexity of institutional individualisation. Ageing Society 38 (3), 594-614.

Gruber, J., Wise, D., 1998. Social security and retirement: an international comparison. Am. Econ. Rev. 88 (2), 158-163.

Guiso, L., Paiella, M., 2008. Risk aversion, wealth, and background risk. J. Eur. Econ. Assoc. 6 (6), 1109-1150.

Hanel, B., 2010. Financial incentives to postpone retirement and further effects on employment-evidence from a natural experiment. Labour Econ. 17 (3), $474-486$.

Hensher, D.A., 1997. Behavioral value of travel time savings in personal and commercial automobile travel. In: Greene, D., Jones, D., Delucchi, M. (Eds.), The Full Costs and Benefits of Transportation. Springer-Verlag, Berlin, pp. 245-280.

Holden, K.C., Burkhauser, R.V., Myers, D.A., 1986. Pensioners' Annuity Choice: Is the Well-Being of Their Widows Considered?. University of Wisconsin Institute for Research on Poverty, Madison (IRP Discussion Paper No. 802-86).

Holden, K.C., Nicholson, S., 1998. Selection of a Joint-And-Survivor Pension. University of Wisconsin-Madison, Institute for Research on Poverty.

Johnson, R.W., Uccello, C.E., Goldwyn, J.H., 2005. Who foregoes survivor protection in employer-sponsored pension annuities? Gerontologist 45 (1), 26-35.

Kangas, O., Lundberg, U., Ploug, N., 2010. Three routes to pension reform: politics and institutions in reforming pensions in Denmark, Finland and Sweden. Soc. Policy Adm. 44 (3), 265-284.

Kantarci, T., Van Soest, A., 2008. Gradual retirement: preferences and limitations. De Economist 156 (2), 113-144.

Kaygusuz, R., 2015. Social security and two-earner households. J. Econ. Dyn. Control 59, 163-178.

Knoef, M.G., Caminada, C.L.J., Been, J., Goudswaard, K.P., 2017. De toereikendheid van pensioenopbouw na de crisis en pensioenhervormingen. Netspar Ind. Pap. Ser..

Laitner, J., Juster, F.T., 1996. New evidence on altruism: a study of TIAA-CREF retirees. Am. Econ. Rev. 893-908.

Laitner, J., Ohlsson, H., 2001. Bequest motives: a comparison of Sweden and the United States. J. Public Econ. 79 (1), 205-236.

Lalive, R., Parrotta, P., 2017. How does pension eligibility affect labor supply in couples? Labour Econ. 46, 177-188.

Larichev, O.I., Moshkovich, H.M., 1988. Limits to decision-making ability in direct multiattribute alternative evaluation. Organ. Behav. Hum. Decis. Process 42 (2), 217-233.

Louviere, J.J., Hensher, D.A., Swait, J.D., 2000. Stated Choice Methods: Analysis and Applications. Cambridge University Press, Cambridge.

Lundberg, S.J., Pollak, R.A., 1993. Separate spheres bargaining and the marriage market. J. Polit. Econ. 101 (6 (December)), $988-1010$.

Lundberg, S.J., Pollak, R.A., 1994. Noncooperative bargaining models of marriage. Am. Econ. Rev. Pap. Proc. 84 (2), $132-137$.

Lundberg, S., Pollak, R.A., Stearns, J., 2016. Family inequality: diverging patterns in marriage, cohabitation, and childbearing. J. Econ. Perspect. 30 (2), 79-102.

Lundberg, S., Startz, R., Stillman, S., 2003. The retirement-consumption puzzle: a marital bargaining approach. J. Public Econ. 87 (5-6), 1199-1218.

Lundberg, S.J., Ward-Batts, J., 2000. Saving for retirement: household bargaining and household net worth. Claremont McKenna College Robert Day School of Economics and Finance Research Paper, (2004-03).

Manser, M., Brown, M., 1980. Marriage and household decision making: a bargaining analysis. Int. Econ. Rev. 21 (1(February)), $31-44$.

Mastrobuoni, G., 2009. Labor supply effects of the recent social security benefit cuts: empirical estimates using cohort discontinuities. J. Public Econ. 93 (11), 1224-1233.

McElroy, M.B., Horney, M.J., 1981. Nash bargained household decisions. Int. Econ. Rev. 22 (2 (June)), 333-349.

Millar, B.G., 1956. The magical number seven, plus or minus two: some limits on our memory for processing information. Psychol. Rev. 63, 81-97.

Motivaction Research and Strategy, 2019. Partnerpensioen Aegon/VU flitscongres 2019 , Amsterdam.

Myers, D.A., Burkhauser, R.V., Holden, K.C., 1987. The transition from wife to widow: the importance of survivor benefits to widows. J. Risk Insurance $752-759$.

Sánchez Martín, R.A., SánchezMarcos, V., 2010. Demographic change and pension reform in Spain: an assessment in a two-earner, Olg model. Fisc. Stud. 31 (3), 405-452.

Nishiyama, S., Smetters, K., 2007. Does social security privatization produce efficiency gains? Q. J. Econ. 122 (4), 1677-1719.

Nishiyama, S., 2019. The joint labor supply decision of married couples and the U.S. social security pension system. Rev. Econ. Dyn. 31, 277-304.

OECD, 2017. Net Pension Replacement Rates (Indicator) . doi: 10.1787/4b03f028-en (Accessed on 15 February 2017).

Peabody, J., Luck, J., Glassman, P., Dresselhaus, T., Lee, M., 2000. Comparison of vignettes, standardized patients, and chart abstraction: a prospective validation study of 3 methods for measuring quality. J. Am. Med. Assoc. 283, 1715-1722.

Peabody, J., Tozija, F., Muňoz, J., Nordyke, R., Luck, J., 2004. Using vignettes to compare the quality of clinical care variation in economically divergent countries. Health Serv. Res. 39, 1951-1970.

Ponds, E.H.M., van Riel, B., 2009. Sharing risk: the Netherlands' new approach to pensions. J. Pension Econ. Finance 8 (1), $91-105$.

Revelt, D., Train, K., 1998. Mixed logit with repeated choices: household choices of appliance efficiency level. Rev. Econ. Stat. 80, 647-657.

Rogers, W.H., 1993. Regression standard errors in clustered samples. Stata Tech. Bull. 13, 19-23.

Shuey, K.M., 2004. Worker preferences, spousal coordination, and participation in an employer-sponsored pension plan. Res. Aging 26 (3), $287-316$.

Simon, H., 1990. Invariants of human behaviour. Annu. Rev. Psychol. 41, 1-19.

Staarink, B., Visser, M., 2017. Survivor's Pension No Longer Assured . Netspar Brief 11 - oktober 2017.

Staubli, S., Zweimüller, J., 2013. Does raising the retirement age increase employment of older workers? J. Public Econ. 108, 17-32.

Telser, H., Zweifel, P., 2007. Validity of discrete-choice experiments evidence for health risk reduction. Appl. Econ. 39, 69-78.

Turner, J.A., 1988. Pension survivors insurance for widows. Econ. Inq. 26, 403-422.

Van Soest, A., Kapteyn, A., Zissimopoulos, J., 2007. Using Stated Preferences Data to Analyze Preferences for Full and Gradual Retirement Institute for the Study of Labor Discussion Paper 2785.

Van Soest, A., Vonkova, H., 2014. How sensitive are retirement decisions to financial incentives? A stated preference analysis. J. Appl. Econometr. 29 (2), $246-264$. 
Vidal-Meliá, C., Lejárraga-García, A., 2006. Demand for life annuities from married couples with a bequest motive. J. Pension Econ. Finance 5 (2), 197-229.

Wilhelm, M.O., 1996. Bequest behavior and the effect of heirs' earnings: testing the altruistic model of bequests. Am. Econ. Rev. 874-892.

Wiswall, M., Zafar, B., 2017. Preference for the workplace, investment in human capital, and gender. Q. J. Econ. 133 (1), 457-507.

Wooldridge, J.M., 2002. Econometric Analysis of Cross Section and Panel Data. MIT Press, Cambridge, MA. 